\title{
Design and optimization of nano invasomal gel of Glibenclamide and Atenolol combination: in vitro and in vivo evaluation
}

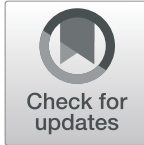

\author{
P. Anitha ${ }^{*^{*}}$ and S. V. Satyanarayana ${ }^{2}$
}

\begin{abstract}
Background: There are many circumstances where chronic disease is associated with other disorders, especially in diseases such as diabetes with noncommunicable disease risk factors, such as hypertension. The current therapies for treating such chronic comorbid diseases are limited and challenging due to the difficulties in overcoming the side effects from complex therapeutic treatment regimen. The present study is aimed to develop and optimize the combinational nano invasomal gel of Glibenclamide (GLB) and Atenolol (ATN) as a novel combination therapy for comorbid treatment of diabetic hypertensive patients. The developed formulations were characterized for various parameters, including in-vitro skin permeation, skin irritation, in-vivo antidiabetic, and antihypertensive activities.

Results: OCNIG showed that the \% entrapment efficiency of GLB is $96.67 \pm 0.65 \%$ and \% entrapment efficiency of ATN is $93.76 \pm 0.89 \%$, flux of GLB $\left(240.43 \pm 1.76 \mu \mathrm{g} / \mathrm{cm}^{2} / \mathrm{h}\right)$, and flux of ATN $\left(475.2 \pm 1.54 \mu \mathrm{g} / \mathrm{cm}^{2} / \mathrm{h}\right)$ which was found to conform to the expected value. The results indicated desired release and permeation profiles. Optimized formulation showed significant pharmacokinetic properties, which shows improvement in bioavailability by $134.30 \%$ and $180.32 \%$ respectively for two drugs, when compared to marketed oral preparation. Pharmacodynamic studies showed improved and prolonged management of diabetes and hypertension in Wistar rats, compared to oral and drug-loaded nano invasomes formulations.
\end{abstract}

Conclusion: Overall, the results showed that nano invasomal gel was found to be a useful and promising transdermal delivery system for the treatment of concurrent diseases.

Keywords: Transdermal delivery, Nano invasomal gel, Atenolol, Glibenclamide, Combination

\section{Background}

Diabetes is a rapidly growing global health issue, partly because of improved living conditions and rising rates of obesity [1]. The incidence of hypertension in the diabetic population is 1.5 to 3 times higher than in the nondiabetic age group [2]. The management and prevention of chronic disease require particular attention to selfmanagement, including the use of a number of medications prescribed for comorbidity [3]. Former surveys have reported that it is related to poor results, including

\footnotetext{
* Correspondence: posina.anitha26@gmail.com

'Department of Pharmaceutics, Research Scholar, JNTUA, Anantapuramu, AP, India

Full list of author information is available at the end of the article
}

mortality, hospitalization, and health maintenance costs in chronically ill patients $[4,5]$. Thus, simultaneous research aims to solve these problems by developing new combinations of fixed doses in two different categories and by applying new routes of administration.

Transdermal administration provides benefits such as avoidance of first-pass effect, control of drug release rate, improved patient compliance, alternative to the immediate end of therapy, etc. [6]. This is most suitable for combination/concomitant diseases that are administered at different timings (before and after food) via the oral route. In recent years, different types of nanocarriers have been designed to improve transdermal drug administration [7].

Springer Open

(s). 2021 Open

(c) The Author(s). 2021 Open Access This article is licensed under a Creative Commons Attribution 4.0 International License, which permits use, sharing, adaptation, distribution and reproduction in any medium or format, as long as you give appropriate credit to the original author(s) and the source, provide a link to the Creative Commons licence, and indicate if changes were made. The images or other third party material in this article are included in the article's Creative Commons licence, unless indicated otherwise in a credit line to the material. If material is not included in the article's Creative Commons licence and your intended use is not permitted by statutory regulation or exceeds the permitted use, you will need to obtain permission directly from the copyright holder. To view a copy of this licence, visit http://creativecommons.org/licenses/by/4.0/. 
Among various nanocarriers, nano invasomes (NI) are efficient carriers for lipophilic and hydrophilic agents [8]. They are mainly composed of Phosphatidyl choline, i.e., soy-phosphatidylcholine, which forms invasomal bilayer and lysophosphatidyl choline acts as edge activator giving flexibility to the bilayer, ethanol and a mixture of terpenes for boosting drug penetration and to give fluidity or flexibility to phospholipids [9].

Gliblenclamide (GLB) is an inexpensive antihyperglycemic drug. GLB is a Biopharmaceutics Classification System (BCS) class II drug, with low oral bioavailability of $\sim 45 \%$ and having a high permeability and low aqueous solubility [10]. GLB has a high dose frequency due to short elimination half-life of $4 \mathrm{~h}$ [11]. Atenolol (ATN) is a beta-adrenergic receptor blocker with no membrane stabilization or intrinsic sympathomimetic activity, which has been used to treat hypertension. It has an oral bio-availability of only $50 \%$ and is partially absorbed by the gastrointestinal tract, while the rest is excreted unchanged in the feces $[12,13]$.

The present research has investigated the possibility of $\mathrm{NI}$ as a new carrier system for combination transdermal administration of GLB and ATN. The preparations were optimized by utilizing a three-factor three-level BoxBehnken design and further evaluated for particle size, shape, ex vivo skin permeation, in vivo drug absorption studies, pharmacokinetics, and pharmacodynamic study.

\section{Methods}

ATN and GLB are gift samples from Sun Pharma Limited in Mumbai, India. Phospholipon $90 \mathrm{G}$ was received as a gift sample from Phospholipid $\mathrm{GmbH}$ Nattermannallee, Germany. D-limonene was received from the Arora Aromatics Private Limited, Sambhal, Uttar Pradesh. Ethanol was procured from E Merck, Mumbai, India. All the reagents used are of analytical grade.

\section{FTIR spectroscopy}

GLB and ATN have been compressed into pellet with $\mathrm{KBr}$ using a hydraulic press. The IR spectra of drugs, ethanol, terpenes, and optimized combinational nano invasomal gel (OCNIG) were recorded in the wave number region of $400-4000 \mathrm{~cm}^{-1}$ in Fourier transform infrared spectroscopy (FTIR) [14].

\section{Preparation of nano-invasomes}

NI was prepared by dissolving Phospholipon ${ }^{\circ} 90 \mathrm{G}$ and drugs in $10 \mathrm{ml}$ chloroform:methanol mixture $(2: 1, \mathrm{v} / \mathrm{v})$ in a round bottom flask of the rotary evaporator (Medica instrument Mfg., Co. Mumbai) [15]. At a temperature above the lipid transition temperature, thin lipid film was produced by evaporation of organic solvents. After the formation of thin films, terpene and ethanol were added, followed by addition of filtered phosphate- buffered saline, $\mathrm{pH}$ 7.4 (PBS). The formed vesicles were sonicated for $15 \mathrm{~min}$ in 3 rounds $(5 \mathrm{~min}$ for each cycle with $5 \mathrm{~min}$ pause among these cycles) with a probe ultrasonicator (Model No. PS500, Ultra autosonic India, Pune) to obtain nano invasomes [16].

\section{Optimization of nano-invasomes by box-Behnken design} Optimization of NI gel by Box-Behnken design was done using Design Expert 11 software. The selected independent variables were phospholipid (mg) (X1), ethanol (\%) (X2), and terpene (\%) (X3) while \% entrapment efficiency (EE) of GLB and ATN (Y1 and Y2), flux of GLB, and ATN (Y3 and Y4) were the dependent variables. All variables were investigated at three different levels (Table 1). The design includes sets of points in the middle of each side and three replicated center points of the multidimensional cube. This experimental design provides fewer numbers (15 runs) of experiments than that provided by a full factorial design (27 runs). Various formulations were formulated based on the selected independent variables, as indicated in Table 2.

\section{$\mathrm{NI}$ characterization $\%$ entrapment efficiency}

The percentage EE was determined by ultracentrifugation method. Samples were centrifuged at 20,000 rpm for $3 \mathrm{~h}$ at $4{ }^{\circ} \mathrm{C}$ in a centrifuge machine (REMI, Mumbai). The collected supernatant was diluted with phosphate buffer saline and quantified by UV spectrophotometer (Shimadzu, Japan) [17]. The \% EE was determined by the following equation [18].

$$
C_{\mathrm{a}}-C_{\mathrm{b}} / C_{\mathrm{a}} \times 100
$$

where $C_{\mathrm{a}}=$ concentration of total drug and $C_{\mathrm{b}}=$ concentration of free drug.

Table 1 Independent and dependent variables used in BoxBehnken design for the development and optimization of $\mathrm{NI}$

\begin{tabular}{llll}
\hline \multirow{2}{*}{$\begin{array}{lll}\text { Indeper } \\
\text { Indepent variables }\end{array}$} & \multicolumn{3}{l}{ Level used, actual coded } \\
\cline { 2 - 4 } & Low (- 1) & Medium (- 1) & High (+ 1) \\
\hline X1 = Phospholipid (mg) & 9 & 11.5 & 14 \\
X2 = Ethanol (\%) & 5 & 7.5 & 10 \\
X3 = Terpene (\%) & 1 & 1.5 & 2 \\
Dependent variables & & & Goal \\
\% EE of GLB (Y1) & & Maximize \\
\% EE of ATN (Y2) & & Maximize \\
Flux of GLB (Y3) & & Maximize \\
Flux of ATN (Y4) & & Maximize \\
\hline
\end{tabular}


Table 2 Observed responses in Box-Behnken design for development and optimization of NI formulations

\begin{tabular}{|c|c|c|c|c|c|c|c|}
\hline Run & $\begin{array}{l}\text { Factor } 1 \\
\text { A:Phospholipid } \\
\% \mathrm{w} / \mathrm{w}\end{array}$ & $\begin{array}{l}\text { Factor } 2 \\
\text { B:Ethanol } \\
\%\end{array}$ & $\begin{array}{l}\text { Factor } 3 \\
\text { C:D-Limonene } \\
\%\end{array}$ & $\begin{array}{l}\text { Response } 1 \\
\text { EE of GLB } \\
\%\end{array}$ & $\begin{array}{l}\text { Response } 2 \\
\text { EE of ATN } \\
\%\end{array}$ & $\begin{array}{l}\text { Response } 3 \\
\text { Flux of GLB } \\
\mu \mathrm{g} / \mathrm{cm}^{2} / \mathrm{h}\end{array}$ & $\begin{array}{l}\text { Response } 4 \\
\text { Flux of ATN } \\
\mu \mathrm{g} / \mathrm{cm}^{2} / \mathrm{h}\end{array}$ \\
\hline 1 & 9 & 7.5 & 1 & $72.54 \pm 0.83$ & $69.54 \pm 1.45$ & $144.3 \pm 0.98$ & $355.8 \pm 1.24$ \\
\hline 2 & 11.5 & 7.5 & 1.5 & $77.96 \pm 0.92$ & $75.54 \pm 1.23$ & $177.9 \pm 1.34$ & $436.7 \pm 0.97$ \\
\hline 3 & 11.5 & 10 & 2 & $70.97 \pm 1.54$ & $67.76 \pm 2.34$ & $160.8 \pm 1.43$ & $380.2 \pm 0.76$ \\
\hline 4 & 11.5 & 5 & 2 & $80.83 \pm 2.23$ & $78.43 \pm 1.23$ & $185.8 \pm 1.67$ & $442.6 \pm 0.45$ \\
\hline 5 & 9 & 5 & 1.5 & $72.54 \pm 1.43$ & $70.54 \pm 0.89$ & $164.3 \pm 2.45$ & $365.8 \pm 0.89$ \\
\hline 6 & 11.5 & 10 & 1 & $72.86 \pm 2.54$ & $71.56 \pm 0.97$ & $150.3 \pm 1.68$ & $405.6 \pm 0.65$ \\
\hline 7 & 11.5 & 7.5 & 1.5 & $77.84 \pm 1.76$ & $75.76 \pm 1.45$ & $180.8 \pm 1.34$ & $440.9 \pm 1.34$ \\
\hline 8 & 11.5 & 5 & 1 & $78.97 \pm 2.65$ & $76.76 \pm 1.34$ & $190.8 \pm 2.56$ & $375.2 \pm 2.98$ \\
\hline 9 & 9 & 10 & 1.5 & $65.95 \pm 2.87$ & $62.98 \pm 1.45$ & $120.3 \pm 2.90$ & $325.5 \pm 2.67$ \\
\hline 10 & 14 & 10 & 1.5 & $90.93 \pm 0.98$ & $87.65 \pm 2.18$ & $215.8 \pm 2.78$ & $465.3 \pm 1.34$ \\
\hline 11 & 11.5 & 7.5 & 1.5 & $78.33 \pm 1.34$ & $76.98 \pm 1.47$ & $185.4 \pm 1.69$ & $450.7 \pm 1.56$ \\
\hline 12 & 9 & 7.5 & 2 & $74.94 \pm 1.56$ & $72.43 \pm 1.45$ & $147.9 \pm 1.34$ & $400.4 \pm 1.67$ \\
\hline 13 & 14 & 5 & 1.5 & $97.62 \pm 0.78$ & $95.76 \pm 1.67$ & $249.3 \pm 0.98$ & $480.1 \pm 2.45$ \\
\hline 14 & 11.5 & 7.5 & 1.5 & $70.97 \pm 1.56$ & $68.76 \pm 0.67$ & $175.8 \pm 0.78$ & $425.2 \pm 2.09$ \\
\hline 15 & 14 & 7.5 & 2 & $94.93 \pm 0.96$ & $91.65 \pm 0.57$ & $240.8 \pm 0.67$ & $479.3 \pm 1.76$ \\
\hline 16 & 11.5 & 7.5 & 1.5 & $77.84 \pm 1.26$ & $75.98 \pm 1.36$ & $186.9 \pm 0.56$ & $444.4 \pm 2.76$ \\
\hline 17 & 14 & 7.5 & 1 & $95.94 \pm 0.56$ & $92.65 \pm 1.35$ & $239.8 \pm 0.65$ & $471.5 \pm 1.45$ \\
\hline
\end{tabular}

\section{Particle size, PDI, and surface charge}

The particle size and polydispersity index (PDI) of the NI formulations were determined by Zetasizer 1000HS (Malvern Instruments, Worcestershire, UK) with photon correlation spectroscopy. Before analyzing, samples were diluted with PBS and filtered through $0.45 \mathrm{~mm}$ membrane filter [19]. The surface charge of drug-entrapped vesicles was estimated with the Zetasizer (Malvern Instruments, Malvern, UK). The average zeta potential of the vesicles was determined [20]. The values presented herein were acquired from three separate experiments, each of which included three replicates; $N=3$.

\section{pH evaluation}

The $\mathrm{pH}$ of OCNIG was determined by means of a $\mathrm{pH}$ meter (Elico) that is diluted in double distilled water by placing it in contact with the gel [20].

\section{Spreadability, homogeneity, and extrudability}

Spreadability was assessed on the basis of slide and swipe character of the gel. Modified method of $0.5 \mathrm{~g}$ gel was placed on a glass plate over which a second glass plate was placed within a premarked circle of $2 \mathrm{~cm}$ diameter. A weight of $500 \mathrm{~g}$ was allowed to rest on the upper glass plate for $5 \mathrm{~min}$. The increase in the diameter due to spreading of the gel was noted [16, 21]. The diameter of gel spreading is increased and the \% spread by area was determined by $(\mathrm{A} 2 / \mathrm{A} 1) \times 100$, where $\mathrm{A} 1$ is $2 \mathrm{~cm}$ and $\mathrm{A} 2$ is a final area after spreading.

By simple visual inspection, the homogeneity of the gels was observed. Extrudability of gels from a collapsible tube was determined by considering the weight in grams required to squeeze $0.5 \mathrm{~cm}$ ribbon of gel in $10 \mathrm{~s}$ [22].

\section{Rheological measurements}

Viscosity of gel was determined by using a Brookfield Viscometer with spindle C50-1, (Model No. LVDVE, Brookfield Engineering Laboratories Inc., Middleboro, MA, USA), at $50 \mathrm{rpm}$ for $50 \mathrm{~s}$ in triplicate [23].

\section{TEM}

The surface structure of diluted OCNIG with distilled water was observed by transmission electron microscopy (TEM) (Jeol electron microscope, Japan). Before the examination, add one drop of the NI suspension $(1 \mathrm{mg} / \mathrm{ml})$ to one drop of potassium phosphotungstate $(2 \%)$ on copper grids, and then air-dried at room temperature [24].

\section{Evaluation of stability of OCNIG}

Stability studies were carried out as per the International Council for Harmonization (ICH) Q1A (R2) guidelines (ICH topic Q1 (R2), 2009). To carry out a stability study, the OCNIG was placed in closed glass vials at $25 \pm 2{ }^{\circ} \mathrm{C} /$ $65 \pm 5 \%, 40 \pm 2{ }^{\circ} \mathrm{C} / 75 \pm 5 \% \mathrm{RH}$ and refrigerated condition $\left(4 \pm 2{ }^{\circ} \mathrm{C}\right)$ for 3 months. Samples were analyzed for 
parameters like clarity, $\mathrm{pH}$, drug content, \%EE, and vesicle size [25].

\section{HPLC determination of GLB and ATN}

The concentration of the combination of GLB and ATN in the samples was analyzed by using high-performance liquid chromatography (HPLC) method (Water 2690 composed of PDA-2996 detector) with BDS C18 $250 \times 2.1$ $\mathrm{mm}, 1.6 \mu$ columns. Data acquisition, recording, and chromatographic integration were performed by Empower 2 software. Mobile phase consisting of $0.01 \mathrm{~N}$ potassium dihydrogen orthophosphate $(\mathrm{pH} 4.8)$ and acetonitrile (ACN) taken at ratio 55:45 with $1.0 \mathrm{ml}$ injection volume in gradient mode with the temperature of the column oven held at $30{ }^{\circ} \mathrm{C}$ and the elution monitored by a detector at a wavelength of $235.0 \mathrm{~nm}$ [26].

\section{In-vitro drug release and release kinetics}

In-vitro drug permeation studies of the optimized formulation were performed by Franz diffusion cells with a diffusional area of $3.14 \mathrm{~cm}^{2}$. An egg layer was set among donor and receptor compartments. The OCNIG was spreaded on egg film. The receptor compartment contained phosphate buffer $\mathrm{pH} 7.4$ and was constantly mixed by remotely determined Teflon-coated magnetic bead. The temperature of the cell was kept up at $37 \pm 1$ ${ }^{\circ} \mathrm{C}$, to mimic the physiological conditions. Aliquots $(1 \mathrm{ml}$ each) were gathered at regular time interval for $24 \mathrm{~h}$ and measured for the two drugs concentration utilizing HPLC technique as depicted previously. Each release study was performed in triplicate [27]. The release kinetics was evaluated to ensure the integrity of fit of different kinetic models [28-30].

\section{Ex-vivo skin permeation study}

Ex vivo skin permeation studies were carried out with the approval from Animal Ethics Committee IAEC (1220/PO/Re/S/08/CPCSEA) by using a Franz diffusion cell with an efficacious permeation area and receptor volume of $3.14 \mathrm{~cm}^{2}$ and $15 \mathrm{ml}$, respectively [31]. The hair on the rabbit skin was removed using hair removal cream, and was wiped with isopropyl alcohol. The receptor compartment (PBS, pH 7.4) was constantly stirred by a magnetic stirrer at $100 \mathrm{rpm}$, which is maintained at 37 $\pm 1{ }^{\circ} \mathrm{C}$. Regular samples were withdrawn at different time intervals up to $24 \mathrm{~h}$ and these were analyzed by HPLC. From the obtained data, flux is calculated by using the below formula [32, 33]. The slope of the linear portion of the curve is calculated for a graph taken cumulative amount permeated per $\mathrm{cm}^{2}$ on $Y$-axis and time on $X$-axis

Steady state flux $\left(J_{\mathrm{ss}}\right)=$ Slope of the linear portion of the curve/ Surface area of diffusion cell
Permeability coefficient $\left(K_{\mathrm{p}}\right)=$ flux/initial concentration of the drug in donor chamber $=J_{\mathrm{ss}} / D_{0}$

\section{In vivo pharmacokinetic study}

The animals used for the study were obtained from NCLA $S$, Hyderabad, and whole experiments were performed at the Annamacharya College of pharmacy, Rajampet. Pharmacokinetic studies were performed on male New Zealand rabbits $(2.5-3.0 \mathrm{~kg})$ and studies were carried out with the approval from Animal Ethics Committee IAEC (1220/ $\mathrm{PO} / \mathrm{Re} / \mathrm{S} / 08 / \mathrm{CPCSEA})$. Rabbits were kept under standard laboratory conditions in $12 \mathrm{~h}$ light/dark cycle at $25 \pm 2{ }^{\circ} \mathrm{C}$ which were fed with food and water. The hair on rabbit skin was shaved before the experiment. The rabbits were divided into three groups; group I was treated as control, group II was given an oral suspension of marketed GLB and ATN, and group III OCNIG was administered. The blood samples were collected at different time intervals $(0$, 2, 4, 6, 8, 12, 24 h) and analyzed by HPLC method [34]. The pharmacokinetic parameters were determined by using Thermo Kinetica (ver. 5.0; Thermo Fischer scientific). Various PK parameters such as $C_{\max }$ (maximum plasma concentration) and $T_{\max }$ (time to maximum plasma concentration) were directly obtained from the plasma concentration versus time curve. The area under the curve from 0 to $\mathrm{t}(\mathrm{AUC0}-24), 0$ to $\infty\left(\mathrm{AUC}_{0-\infty}\right)$, area under the first moment curve from 0 to $24\left(\mathrm{AUMC}_{0-24}\right) 0$ to $\infty\left(\mathrm{AUMC}_{0-\infty}\right)$ were computed by trapezoid rule and elimination half-life $\left(t_{1 / 2}\right)$ was calculated by using the formula $t_{1 / 2}=\log 2 / \mathrm{Kel}$. The relative bioavailability $(F \%)$, defined as the ratio of $\mathrm{AUC}_{0-\infty}$ of each transdermal system to that of the orally administered at the same doses, was also calculated.

\section{Skin irritation study}

The study was performed by using healthy Male Newzeland Rabbits $(2.5-3.0 \mathrm{~kg})$. For the study, the rabbits were divided into three groups. Group 1 served as a control, group 2 received blank nano invasomal gel, and group 3 received OCNIG on the shaven side of rabbits. The study was carried out as per the Draize scoring system (Table 3) $[35,36]$. The responses scored after removing test and the standard at 1, 2, 3, and on the 7th day and they were examined for any signs of erythema and edema. All animals used in the experiment were rehabilitated in animal house. No surgical procedure was performed on rabbits and all animals used were sent for rehabilitation treatment after experimentation to the point of returning to normal existence and the care of such an animal has been taken over its intended statistical life. 
Table 3 Draize score evaluation criteria for skin irritation study

\begin{tabular}{llll}
\hline Value & Erythema & Value & Edema formation \\
\hline 0 & No erythema & 0 & No edema \\
1 & Very slight erythema, & 1 & Very slight edema \\
2 & Slight erythema & 2 & Slight edema \\
3 & Moderate to severe erythema & 3 & Moderate edema $(1 \mathrm{~mm})$ \\
4 & Severe erythema & 4 & Severe edema \\
\hline
\end{tabular}

\section{Pharmacodynamic study}

The animals used for the study were obtained from animal house, and whole experiments were performed at the CAPE biolabs, Marthandam with a written consent. Animal experiments were done as per the standards and guidelines set by the institutional animal ethical committee (IAEC No. CBLRC/IAEC/13/01-2019). All Wistar albino rats (150-180 g) were fed ad libitum and housed in light and dark cycle in an ambient temperature-controlled environment [37]. No surgical procedure was performed on rats and all animals used were sent for rehabilitation treatment after experimentation to the point of returning to a normal existence and the care of such an animal has been taken over its intended statistical life.

\section{Anti-diabetic activity of OCNIG in rats}

The rats were rendered diabetic by an intraperitoneal injection of streptozocin (50 mg/kg body weight) in $\mathrm{pH} 4.5$ citrate buffer after fasting for $30 \mathrm{~h}$. The blood glucose > $250 \mathrm{mg} / \mathrm{dl}$ were selected after $24 \mathrm{~h}$. The rats were divided into 3 groups $(n=6)$. Group 1 -given oral marketed suspension GLB, group 2-GLB (single drug) NI gel (NIG), and group 3-OCNIG (ATN and GLB combination) was applied on the previously shaven dorsal side of rats. To secure it firmly at the application site, a tape was wrapped on the gel formulation. Blood samples were collected from Retro Orbital-Sinuses of rats after euthanized with ketamine $(100 \mathrm{mg} / \mathrm{kg}$, intramuscularly) and the blood glucose level of each rat was measured at the interval of $0,2,4,6$, 8,12 , and $24 \mathrm{~h}$ using the One Touch glucometer [38].

\section{Antihypertension activity of OCNIG in rats}

Hypertension is induced by subcutaneous injection of Methyl Prednisolone acetate $(20 \mathrm{mg} / \mathrm{kg} /$ week $)$ for 3 weeks in rats, and the systolic blood pressure (SBP) was measured by tail-cuff method (NIBP system IN125/R; AD Instrument Pvt. Ltd., Australia) and rats with the systolic pressure (SBP) > $130 \mathrm{mmHg}$ were then selected for the experiment [39]. The rats were divided into 3 groups as follows: group 1 -oral administration of suspension of the marketed ATN, group 2-ATN (single drug) NI gel, and group 3-OCNIG (both drugs-ATN and GLB) was applied on the previously shaven dorsal side of rats. To secure it firmly at the application site, a tape was wrapped on the gel formulation. SBP levels were measured just before and at $0,2,4,6,8,12$, and 24 h using the tail-cuff system [40, 41].

\section{Statistical analysis}

Data from various endpoints were statistically assessed using analysis of variance (ANOVA) followed by the Tukey tests, and mean values were considered for the respective endpoints. All the values were expressed as mean $\pm \operatorname{SEM}(n=6)$.

\section{Results \\ FTIR spectroscopy}

The IR spectra of pure drugs have shown peaks at $1515.29 \mathrm{~cm}^{-1}$ and $1521.99 \mathrm{~cm}^{-1} \quad(\mathrm{~N}=\mathrm{N}$ stretching), $1242.08 \mathrm{~cm}^{-1}$ and $1246.56 \mathrm{~cm}^{-1} \quad(\mathrm{C}=\mathrm{C}$ stretching), $2924.46 \mathrm{~cm}^{-1}$ and $2931.19 \mathrm{~cm}^{-1}\left(\mathrm{CH}_{3}\right.$ stretching $)$, $1415.09 \mathrm{~cm}^{-1}$ and $1455.35 \mathrm{~cm}^{-1}\left(\mathrm{CH}_{3}\right.$ deformation), and $3356.86 \mathrm{~cm}^{-1}$ and $3367.54 \mathrm{~cm}^{-1}$ (O-H Stretching) for ATN and GLB respectively [42]. The FTIR spectra of GLB, ATN, Phospholipid ${ }^{\circledR}$ 90G, D-limonene, and OCNIG are depicted in Fig. 1

Optimization of nano-invasomes by box-Behnken design A 3-factor, 3-level Box-Behnken design was applied to investigate quadratic response surfaces with Design Expert 11 (Version 11.0, Stat-Ease Inc.). Table 2 provides the results of 17 runs and the responses of the prepared formulations. These 3D-plots are known to study the interaction effects of the factors on the responses as well as are useful in studying the effects of two factors on the response at one time which is shown in Fig. 2. Actual and predicted values as linear correlation plots and the corresponding residual plots for various responses were shown in Fig. 3.

\section{Response 1 (Y1): effect of independent variables on \% EE of GLB}

A UV spectrophotometric method was applied for the determination of \%EE the prepared formulations. The calibration curves of GLB and ATN were prepared in phosphate buffer $\mathrm{pH} 7.4$ and found linear over the concentration range of $2-12 \mu \mathrm{g} / \mathrm{ml}$ and $10-50 \mu \mathrm{g} / \mathrm{ml}$ respectively with coefficient of determination $\left(r^{2}\right)$ of 0.998 and 0.999 respectively.

The model- $F$ value 23.89 was found to suggest that the model was significant. There is only a $0.01 \%$ chance that such a high $F$ value may occur as a result of noise. Values of "Prob> $F$ " less than 0.0500 indicate that model terms were significant. Here $\mathrm{X} 1, \mathrm{X} 2, \mathrm{X} 1^{2}$ are significant model terms. The lack of fit $F$ value 0.23 means it is not significant with respect to the pure error. The $p$ value of the ANOVA model is 0.0002 which indicates the model was significant. 


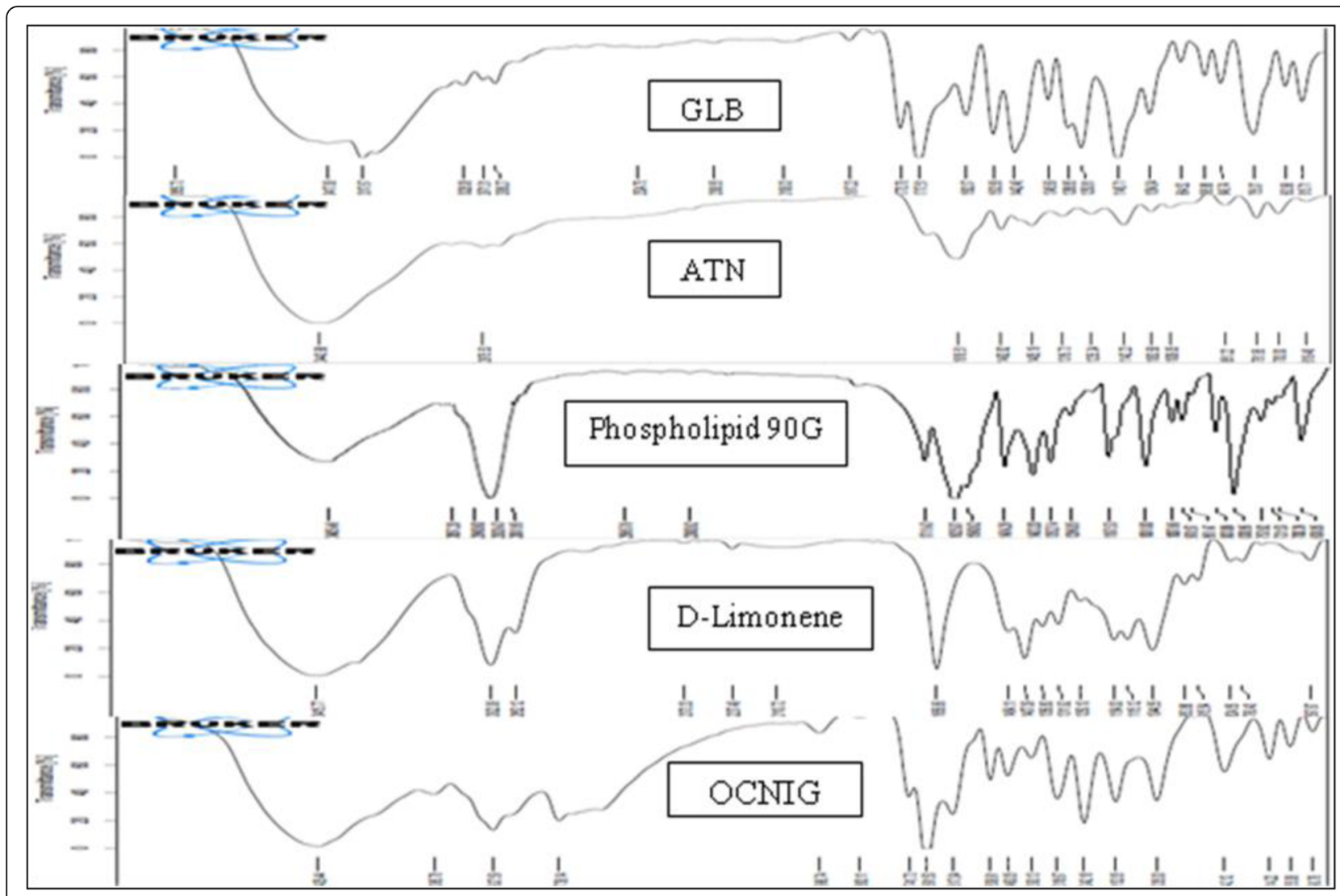

Fig. 1 FTIR spectroscopy images

$$
\begin{aligned}
\% \mathrm{EE} \text { of } \mathrm{GLB}= & +76.59+11.68 \mathrm{X} 1-3.66 \mathrm{X} 2 \\
& +0.1700 \mathrm{X} 3-0.025 \mathrm{X} 1 \mathrm{X} 2-0.8525 \mathrm{X} 1 \mathrm{X} 3 \\
& -0.9375 \mathrm{X} 2 \mathrm{X} 3+6.93 \mathrm{X}^{2}-1.75 \mathrm{X}^{2}+1.07 \mathrm{X}^{2}
\end{aligned}
$$

The ratio is 15.546 indicating the correct signal. The predicted $R^{2}$ of 0.8847 is in reasonable accord with the adjusted $R^{2}$ of 0.9279 .

\section{Response 2 (Y2): effect of independent variables on \% EE of ATN}

The model $F$ value 20.17 suggested that the model was significant. There is only a $0.03 \%$ chance that such a high $F$ value may occur as a result of noise. Here $\mathrm{X} 1$, $\mathrm{X} 2, \mathrm{X}^{2}$ are significant model terms. The $F$ value of the lack of fit 0.28 means that the lack of fit is not significant with respect to the pure error. The $p$ value of the ANOVA model is 0.0003 which indicates model is significant.

$$
\begin{aligned}
\% \mathrm{EE} \text { of } \mathrm{ATN}= & +74.60+11.53 \mathrm{X} 1-3.94 \times 2-0.0300 \mathrm{X3} \\
& -0.1375 \mathrm{X} 1 \mathrm{X} 2-0.9725 \mathrm{X} 1 \mathrm{X} 3-1.37 \mathrm{X} 2 \mathrm{X} 3 \\
& +6.28 \mathrm{X}^{2}-1.66 \mathrm{X}^{2}+0.6793 \mathrm{X3}^{2}
\end{aligned}
$$

The ratio is 14.651 indicating the correct signal. The predicted $R^{2}$ of 0.8494 is in reasonable accord with the adjusted $R^{2}$ of 0.9151 .

\section{Response 3 (Y3): effect of independent variables on flux of GLB}

The model $F$ value 138.43 suggested that the model was significant. There is only a $0.01 \%$ chance that such a high $F$ value may occur as a result of noise. Here $\mathrm{X} 1$, $\mathrm{X} 2, \mathrm{X}^{2}, \mathrm{X}^{2}$ are significant model terms. The $F$ value of the lack of fit 0.38 means that the lack of fit is not significant with respect to the pure error. The $p$ value of the ANOVA model is $<0.0001$ which indicates the model is significant. The predicted $R^{2}$ of 0.9733 is in reasonable accord with the adjusted $R^{2}$ of 0.9872 .

$$
\begin{aligned}
\text { Flux of GLB }(\mathrm{Y} 3)= & +181.36+46.11 \mathrm{X} 1-17.87 \mathrm{X} 2 \\
& +1.26 \mathrm{X3} \\
& +2.62 \mathrm{X} 1 \mathrm{X} 2-0.6500 \mathrm{X} 1 \mathrm{X} 3 \\
& +3.88 \mathrm{X} 2 \mathrm{X3} \\
& +13.67 \mathrm{X}^{2}-7.61 \mathrm{X}^{2}-1.83 \mathrm{X3}^{2}
\end{aligned}
$$

The 3D-response graph (Fig. 2c) showed that flux increased with increase in phospholipid level. The formulations with highest phospholipid levels $(14 \%$ w/w) F13 and F15 showed the higher transdermal flux than that formulation F1, and F9 with low levels of phospholipid $(9 \% \mathrm{w} / \mathrm{w})$. 


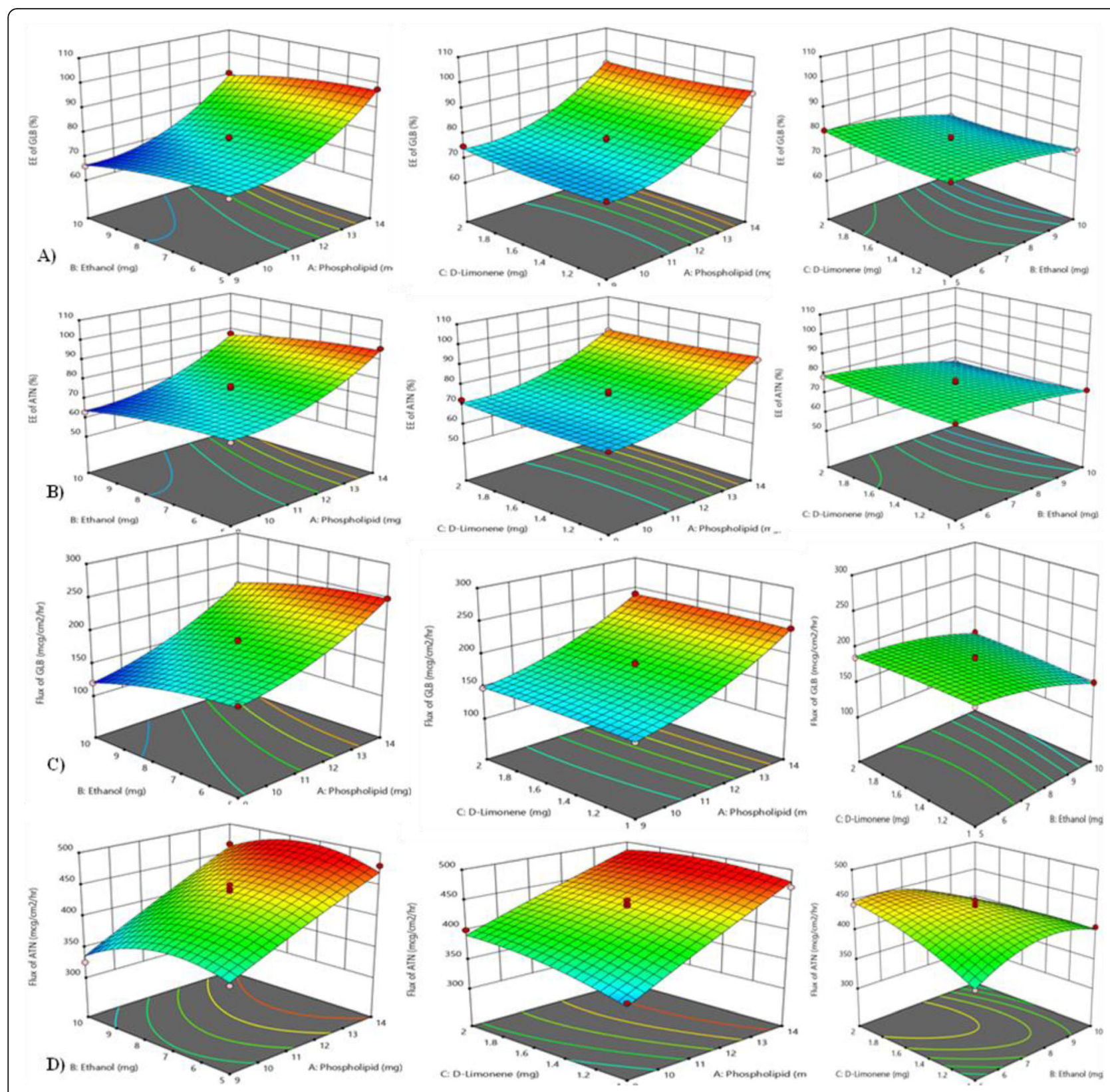

Fig. 2 3D-Response surface plots presenting the effect of three selected factors on a \% EE of GLB, $\mathbf{b} \%$ EE of ATN, and $\mathbf{c}$ flux of GLB and $\mathbf{d}$ flux of ATN

\section{Response 4 (Y4): effect of independent variables on flux of ATN}

The model- $F$ value 29.75 suggested that the model was significant. There is only a $0.01 \%$ chance that such a high $F$ value may occur as a result of noise. Here X1, $\mathrm{X} 2, \mathrm{X} 3, \mathrm{X} 2 \mathrm{X} 3, \mathrm{X} 2^{2}$ are significant model terms. The $F$ value of the lack of fit 1.92 means that the lack of fit is not significant with respect to the pure error. The $\mathrm{p}$ value of the ANOVA model is $<0.0001$ which indicates model is significant. The predicted $R^{2}$ of 0.7433 is in reasonable accord with the adjusted $R^{2}$ of 0.9418 .

\section{Flux of ATN $(\mathrm{Y} 4)=+439.58+56.09 \mathrm{X} 1-10.89 \mathrm{X} 2$ $+11.80 \mathrm{X} 3+6.37 \mathrm{X} 1 \mathrm{X} 2-9.20 \mathrm{X} 1 \mathrm{X} 3$ $-23.20 \mathrm{X} 2 \mathrm{X} 3-2.28 \mathrm{X}^{2}-28.13 \mathrm{X}^{2}-10.55 \mathrm{X3}^{2}$}

The 3D-response graph (Fig. 2d) showed that flux increased with increase in phospholipid level. The formulations with highest phospholipid levels (14\% w/w) F13 and F15 showed the higher transdermal flux than that formulation F1, and F9 with low levels of phospholipid $(9 \% \mathrm{w} / \mathrm{w})$. Summary of results of regression analysis for responses $\mathrm{Y} 1, \mathrm{Y} 2, \mathrm{Y} 3$, and $\mathrm{Y} 4$ for fitting to quadratic model were given in Table 4. 


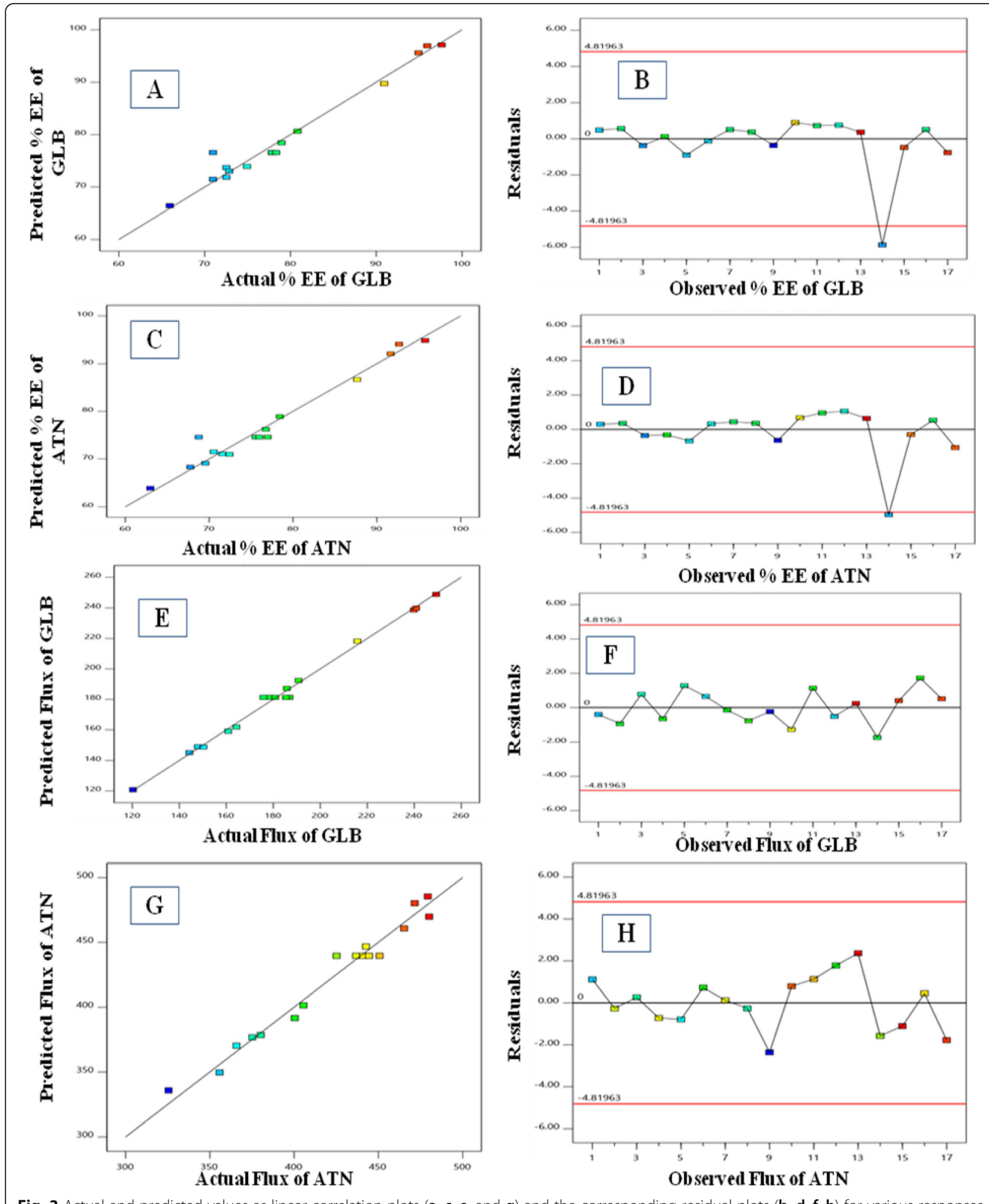

Fig. 3 Actual and predicted values as linear correlation plots ( $\mathbf{a}, \mathbf{c}, \mathbf{e}$, and $\mathbf{g}$ ) and the corresponding residual plots (b, d, $\mathbf{f}, \mathbf{h})$ for various responses

The optimization was done based on the principle of achieving the desirable values of \% $\mathrm{EE}$, transdermal flux by applying numerical point prediction method. The formulation composition with phospholipid (14 mg), ethanol (5\%), and D-limonene (1.78\%) has been found to comply with the requirements. The OCNIG presented 
the practical values of \%EE of GLB is $96.67 \pm 0.65 \%$, $\%$ EE of ATN is $93.76 \pm 0.89 \%$, and flux of GLB (240.43 $\left.\pm 1.76 \mu \mathrm{g} / \mathrm{cm}^{2} / \mathrm{h}\right)$ and flux of ATN $(475.2 \pm 1.54 \mu \mathrm{g} /$ $\mathrm{cm}^{2} / \mathrm{h}$ ). These practical values of $\% \mathrm{EE}$ and transdermal flux yielded by the OCNIG formulation were found in conformity with the predicted value of \% EE of GLB is $97.62 \pm 0.85 \%$, \%EE of ATN is $95.27 \pm 0.67 \%$, and transdermal flux of GLB is $246.32 \pm 2.56\left(\mu \mathrm{g} / \mathrm{cm}^{2} / \mathrm{h}\right)$, flux of ATN is $481.08 \pm 2.46 \mu \mathrm{g} / \mathrm{cm}^{2} / \mathrm{h}$ respectively.

\section{$\mathrm{NI}$ characterization}

The particle size of OCNIG formulation was found to be $125.35 \pm 3.25 \mathrm{~nm}$ with a polydispersity index of $0.223 \pm$ 0.012 . The value of $\mathrm{pH}$ was found as $6.9 \pm 0.1$. The viscosity of OCNIG was found to be $39.00 \mathrm{~Pa}$ s. The surface charge of OCNIG was - 18. $6 \pm 0.3 \mathrm{mV}$. Smooth and spherical structure conformed by TEM. The images were shown in Figs. 4, 5, and 6.

\section{Evaluation of stability of OCNIG}

Stability of OCNIG was studied by evaluating clarity, $\mathrm{pH}$, drug content, $\mathrm{EE}$, and vesicle size after storage. The evaluation of stability of OCNIG was given in Table 5 .

\section{HPLC determination of GLB and ATN}

An isocratic LC method, coupled with PDA detection, was developed for the simultaneous determination of ATN and GLB. Chromatogram A and chromatogram B represents the blank mobile phase and an average retention time of 2.322 min for GLB and $3.260 \mathrm{~min}$ for ATN, with no interfering peaks respectively in Fig. 7. According to ICH guidelines (International Council for Harmonization), this method was validated. The validation characteristics were addressed in our earlier work [26].

\section{In vitro drug release and release kinetics}

The highest value of the coefficient of determination $\left(R^{2}=\right.$ 0.986 for GLB and $R^{2}=0.996$ for ATN) was observed in the Higuchi matrix model [28], Korsmeyer-Peppas [29] $\left(R^{2}=0.976\right.$ for GLB and $R^{2}=0.984$ for ATN $)$, and zero order $\left(R^{2}=0.857\right.$ for GLB and $R^{2}=0.868$ for ATN $)$.

\section{Ex vivo skin permeation study}

The release profile of the drugs loaded OCNIG was superior to that of control patches which is given in our earlier work [30]. These were confirmed by the flux values $\left(U_{\mathrm{ss}}\right)$ which were given in Table 6 . The ex-vivo permeation profile of OCNIG yielded higher flux value, i.e., $240.43 \pm 1.76 \mu \mathrm{g} / \mathrm{cm}^{2} / \mathrm{h}$ for GLB and $475.2 \pm 1.54$ $\mu \mathrm{g} / \mathrm{cm}^{2} / \mathrm{h}$. Ex vivo skin permeation profile of OCNIG was shown in Fig. 8.

\section{In vivo pharmacokinetic study}

The plasma concentration-time profiles of GLB and ATN of marketed suspension and OCNIG are shown in Fig. 9. The pharmacokinetic parameters were given in Table 7. The OCNIG exhibited the $C_{\max }$ of $151.76 \pm$ $12.15 \mathrm{ng} / \mathrm{ml}$ for GLB and $127.64 \pm 10.06 \mathrm{ng} / \mathrm{ml}$ for ATN $(p<0.0001)$, whereas marketed oral solution of GLB and ATN have $C_{\max }$ of $251.58 \pm 10.5 \mathrm{ng} / \mathrm{ml}$ and $177.62 \pm$ $10.14 \mathrm{ng} / \mathrm{ml}$, respectively. The AUC represents the bioavailability from its dosage form. It was observed that significantly high $(p<0.002) \mathrm{AUC}_{(0-24)}$ and $\mathrm{AUC}_{(0-\infty)}$ for OCNIG GLB and ATN was $2930.21 \pm 3.15 \mathrm{ng} \mathrm{h} / \mathrm{ml}$; $3362.37 \pm 2.22 \mathrm{ng} \mathrm{h} / \mathrm{ml}$ and $2838.94 \pm 1.91 \mathrm{ng} \mathrm{h} / \mathrm{ml}$; $3122.55 \pm 1.35 \mathrm{ng} \mathrm{h} / \mathrm{ml}$, whereas for market preparation is $2226.88 \pm 2.31 \mathrm{ng} \mathrm{h} / \mathrm{ml} ; 2357.93 \pm 1.24 \mathrm{ng} \mathrm{h} / \mathrm{ml}$ and $1422.6 \pm 2.58 \mathrm{ng} \mathrm{h} / \mathrm{ml} ; 1576.48 \pm 4.24$ respectively. The relative bioavailability of NI of GLB and ATN was found to be $134.30 \%$ and $180.32 \%$ compared to marketed oral preparation.

Time taken to achieve the $T_{\max }$ was fundamentally delayed in OCNIG. These values were significantly higher as compared to marketed oral suspension $(p<0.002)$. The $t_{1 / 2}$ of $17.087 \pm 1.24 \mathrm{~h}$ for GLB and $14.786 \pm 1.23 \mathrm{~h}$ for ATN in plasma was noticed after the application of OCNIG.

\section{Skin irritation studies}

No observable erythema and edema was observed on the Male Newzeland Rabbit skin after one week of application. Table 8 shows Draize score for all groups of rabbits.

\section{Pharmacodynamic study Anti-diabetic activity of OCNIG in rats}

The results indicated a reduction in plasma glucose levels in a transdermal gel containing OCNIG compared to the oral administration of GLB and ATN in diabetic rats. ONIG-treated rats showed statistically significant decrease in blood glucose levels when compared with marketed PIO-treated rats up to $24 \mathrm{~h}(p<0.002)$. The

Table 4 Summary of results of regression analysis for responses $Y 1, Y 2$, and $Y 3$ for fitting to quadratic model

\begin{tabular}{llllll}
\hline Quadratic model & Sequential $\boldsymbol{p}$ value & Lack of fit $\boldsymbol{F}$ value & Lack of fit $\boldsymbol{p}$ value & Adjusted $\boldsymbol{R}^{\mathbf{2}}$ & Predicted $\boldsymbol{R}^{\mathbf{2}}$ \\
\hline Response (Y1) & 0.0049 & 0.2261 & 0.2261 & 0.9279 & 0.8847 \\
Response (Y2) & 0.0124 & 0.2785 & 0.8391 & 0.9151 & 0.8494 \\
Response (Y3) & 0.0008 & 0.3828 & 0.7719 & 0.9872 & 0.9733 \\
Response (Y4) & 0.0054 & 1.92 & 0.2684 & 0.9418 & 0.7433 \\
\hline
\end{tabular}




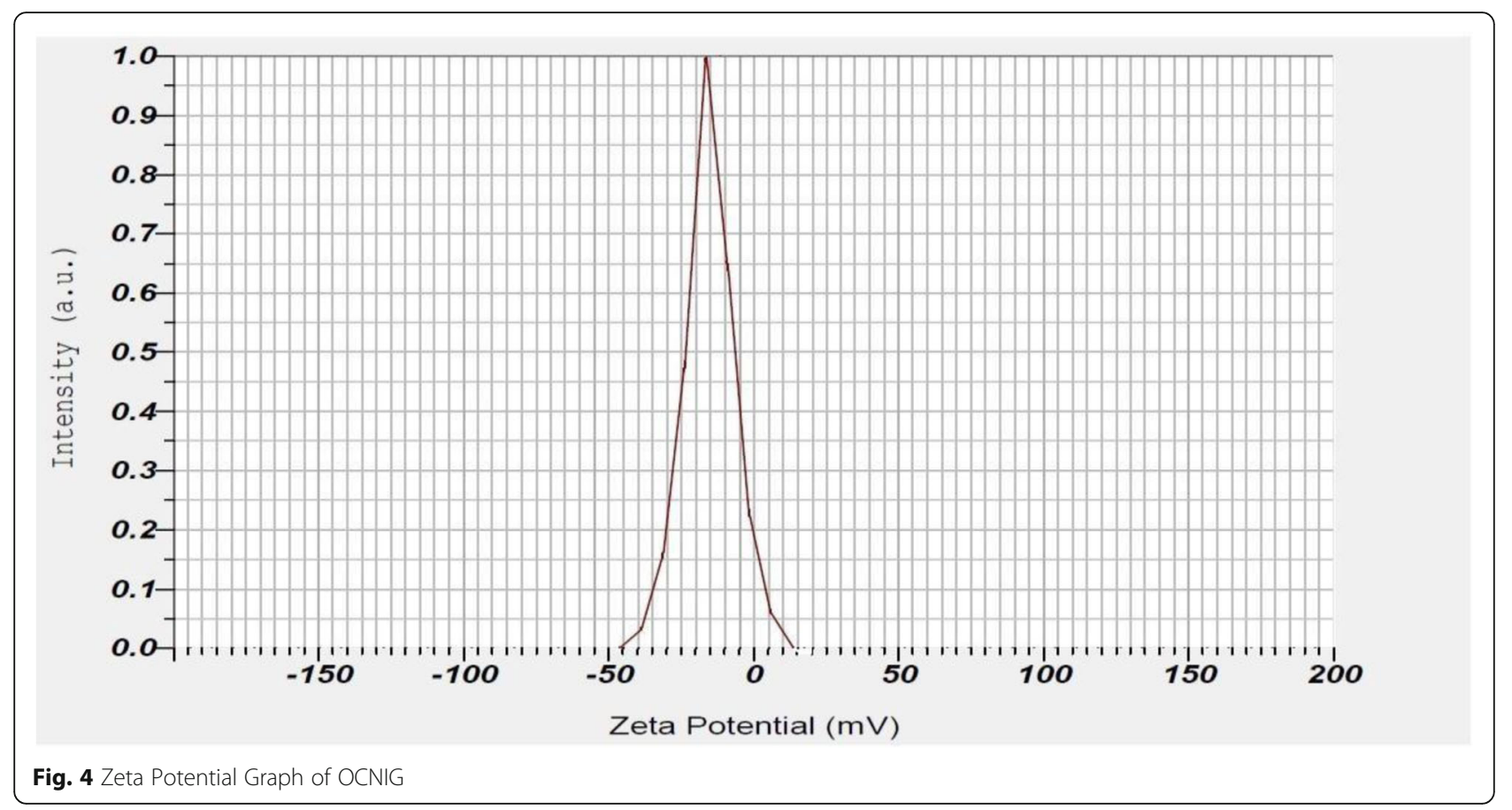

marketed formulation showed blood glucose level of $90.12 \pm 5.26 \mathrm{mg} / \mathrm{dl}(p<0.005)$ at the $4^{\text {th }} \mathrm{h}$. As for the ONIG, the reduction of blood glucose level was steady and stable. The maximum response was observed after the $6^{\text {th }} \mathrm{h}$ and remained constant up to $24 \mathrm{~h}$ (Fig. 7). In the initial $4 \mathrm{~h}$, the hypoglycemic effect produced by TDDS in the animals is significantly less when compared to oral administration. The plasma insulin level was elevated to the maximum in oral, transdermal system treated groups at $4 \mathrm{~h}$ and $6 \mathrm{~h}$ respectively (Fig. 10).

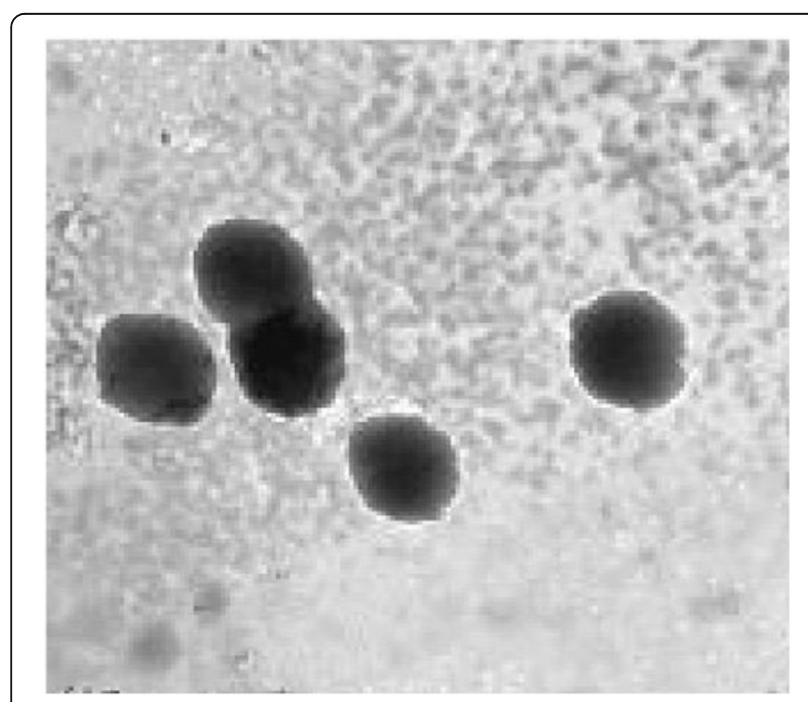

Fig. 5 TEM image of OCNIG

\section{Antihypertension activity of OCNIG in rats}

There was a significant difference in SBP values before and after treatment with methyl Prednisolone acetate in Wistar albino rats. The changes in SBP $(\mathrm{mmHg})$ after administration of marketed ATN, ATN NIG, and OCNIG are presented in Fig. 11. Systolic blood pressure was significantly reduced to normal value at $2 \mathrm{~h}$ with the highest reduction in SBP $(120.67 \pm 3.32 \mathrm{mmHg})$. SBP progressively started to rise after $6 \mathrm{~h}$ and reached up to $125.0 \pm 3.66 \mathrm{mmHg}$ at $12 \mathrm{~h}$ and $130.83 \pm 4.75 \mathrm{mmHg}$ at $24 \mathrm{~h}$. When compared with oral, the observed effect was found to be significant $(p<0.002)$ in case of OCNIG-treated rats. However, ATN-loaded NIG formulation progressively decreased the SBP, and maximum action of the drug was observed at $4 \mathrm{~h}$ following transdermal application of ONIG (SPB of $102.50 \pm 4.68 \mathrm{mmHg}$ ) in hypertensive rats, similar to the effect to group 2, which is similar to findings of previous work [35]. The reduction in blood pressure of OCNIG was sustained and maintained till $24 \mathrm{~h}$.

\section{Discussion}

FTIR spectroscopy

From the spectra of individual drugs and excipients, we can conclude that desired functional group frequencies are replicable in OCNIG. However, there were other peaks in the physical mixture that could be due to the presence of additives as seen in the previous work [43]. 


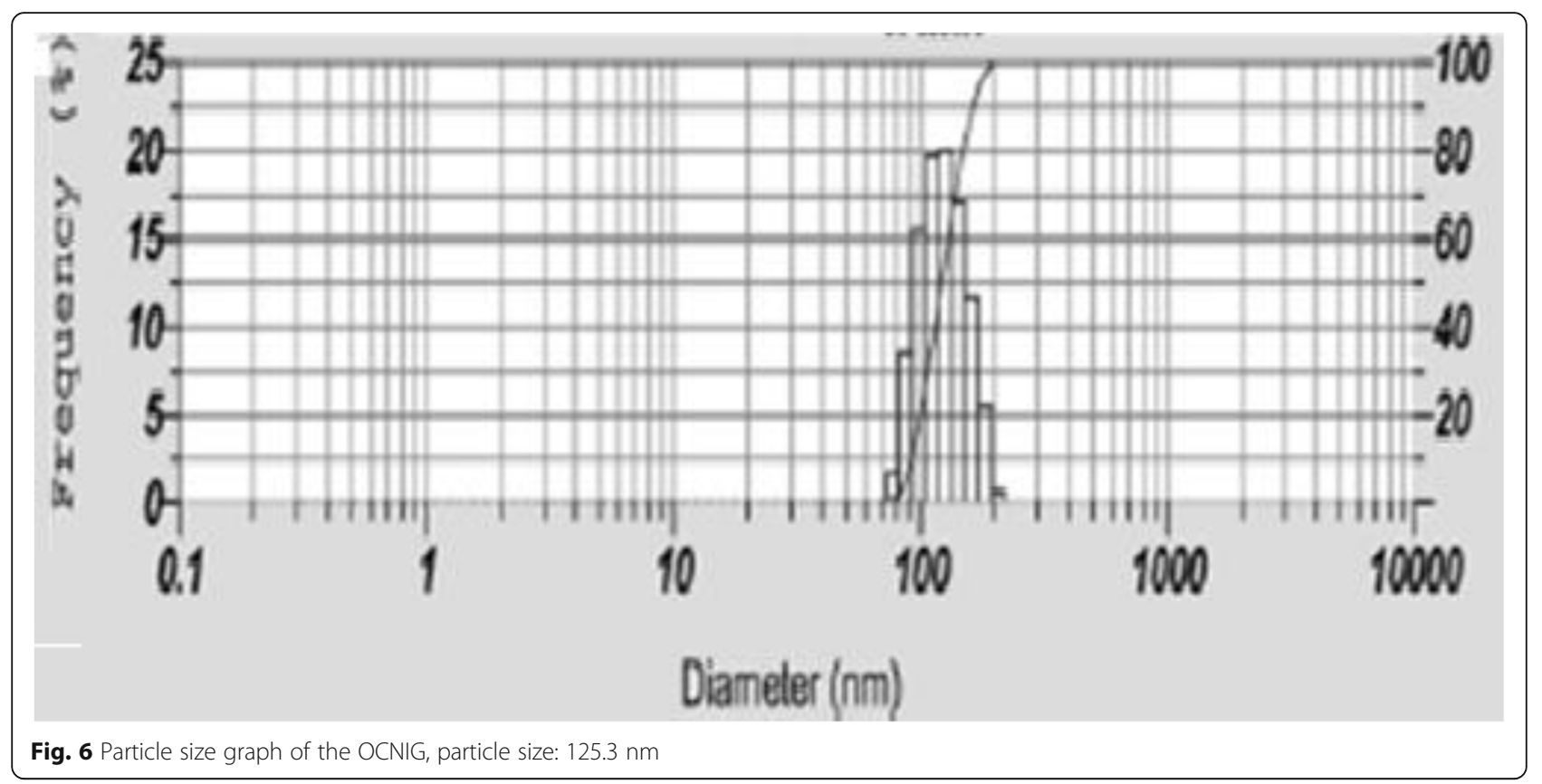

\section{Optimization of nano-invasomes by Box-Behnken design Response 1 (Y1): effect of independent variables on \% EE of GLB}

In view of all 17 formulations, the average GLB \%EE was found to be $79.52 \%$, with least and highest value of $65.95 \%$ and $97.62 \%$, respectively. Phospholipid levels had a considerable effect on \%EE. The 3D-Response graph (Fig. 2a) showed greater \%EE of GLB with increased phospholipid content. Furthermore, ethanol, D-limonene, and the nature of the drug also play an important role in the \%EE, as the drug is trapped in the lipid phase. GLB is a lipophilic drug, hence that the entrapment efficiency noticeably was found to be more eminent. It was noted that the formulations with highest phospholipid level $(14 \% \mathrm{w} / \mathrm{w})$ showed higher \%EE compared to lowest phospholipid level (9\% w/ w). The 3D graph showed that the Y1 (\%EE) response has an opposite effect with ethanol, which is similar to the earlier work [16, 44]. In addition, terpene (D-limonene) showed positive effects with \%EE.
Response 2 (Y2): effect of independent variables on \% EE of ATN

In view of all 17 formulations, the average ATN \%EE was found to be $77.90 \%$, with least and highest value of $62.98 \%$ and $95.76 \%$, respectively. Phospholipid levels had a significant effect on \%EE. The 3D-response graph (Fig. 2b) demonstrated that a similar effect is found in \% EE of ATN as that of GLB. \%EE of ATN was found less when compared with GLB as it is a hydrophilic drug which is similar to findings of Badran et al. [45].

\section{Response 3 (Y3): effect of independent variables on flux of GLB}

Transdermal flux increases with ethanol and terpene combination which is in agreement with Hofland et al. [46] (Fig. 2c). Penetration studies exposed noteworthy penetration of the drug through the skin via invasome. Moreover, invasomes having limonene showed additional penetration because of its higher lipophilicity and

Table 5 Evaluation of stability of OCNIG

\begin{tabular}{|c|c|c|c|c|c|}
\hline \multirow{2}{*}{$\begin{array}{l}\text { S. } \\
\text { No. }\end{array}$} & \multirow{2}{*}{$\begin{array}{l}\text { Characterization } \\
\text { of OCNIG }\end{array}$} & \multirow[t]{2}{*}{ Freshly prepared (initial) } & \multicolumn{3}{|l|}{ After 3 months } \\
\hline & & & $25 \pm 2{ }^{\circ} \mathrm{C} / 65 \pm 5 \%$ & $40 \pm 2^{\circ} \mathrm{C} / 75 \pm 5 \% \mathrm{RH}$ & $\begin{array}{l}\text { Refrigerated condition } \\
\left(4 \pm 2{ }^{\circ} \mathrm{C}\right)\end{array}$ \\
\hline 1 & Clarity & $\begin{array}{l}\text { Clear, smooth and } \\
\text { homogenous }\end{array}$ & $\begin{array}{l}\text { Clear, smooth and } \\
\text { homogenous }\end{array}$ & $\begin{array}{l}\text { Clear, smooth and } \\
\text { homogenous }\end{array}$ & $\begin{array}{l}\text { Clear, smooth and } \\
\text { homogenous }\end{array}$ \\
\hline 2 & $\mathrm{pH}$ & $6.8 \pm 0.1$ & $6.75 \pm 0.1$ & $6.78 \pm 0.1$ & $6.7 \pm 0.2$ \\
\hline 3 & Drug Content (\%) & $\begin{array}{l}98.43 \pm 0.023 \text { (GLB) } \\
97.89 \pm 0.026 \text { (ATN) }\end{array}$ & $\begin{array}{l}97.33 \pm 0.012 \text { (GLB) } \\
97.21 \pm 0.016 \text { (ATN) }\end{array}$ & $\begin{array}{l}97.12 \pm 0.01 \text { (GLB) } \\
97.01 \pm 0.012 \text { (ATN) }\end{array}$ & $\begin{array}{l}97.09 \pm 0.02 \text { (GLB) } \\
96.21 \pm 0.04 \text { (ATN) }\end{array}$ \\
\hline 4 & $\begin{array}{l}\text { Entrapment Efficiency } \\
(\%)\end{array}$ & $\begin{array}{l}97.34 \pm 0.034(\mathrm{GLB}) \\
96.89 \pm 0.015 \text { (ATN) }\end{array}$ & $\begin{array}{l}97.04 \pm 0.015(\text { GLB }) \\
95.99 \pm 0.025 \text { (ATN) }\end{array}$ & $\begin{array}{l}97.34 \pm 0.012 \text { (GLB) } \\
95.25 \pm 0.055 \text { (ATN) }\end{array}$ & $\begin{array}{l}96.04 \pm 0.013(\mathrm{GLB}) \\
94.89 \pm 0.04 \text { (ATN) }\end{array}$ \\
\hline 5 & Vesicle size (nm) & $120.45 \pm 3.87$ & $120.08 \pm 2.65$ & $124.08 \pm 2.65$ & $130.08 \pm 2.65$ \\
\hline
\end{tabular}




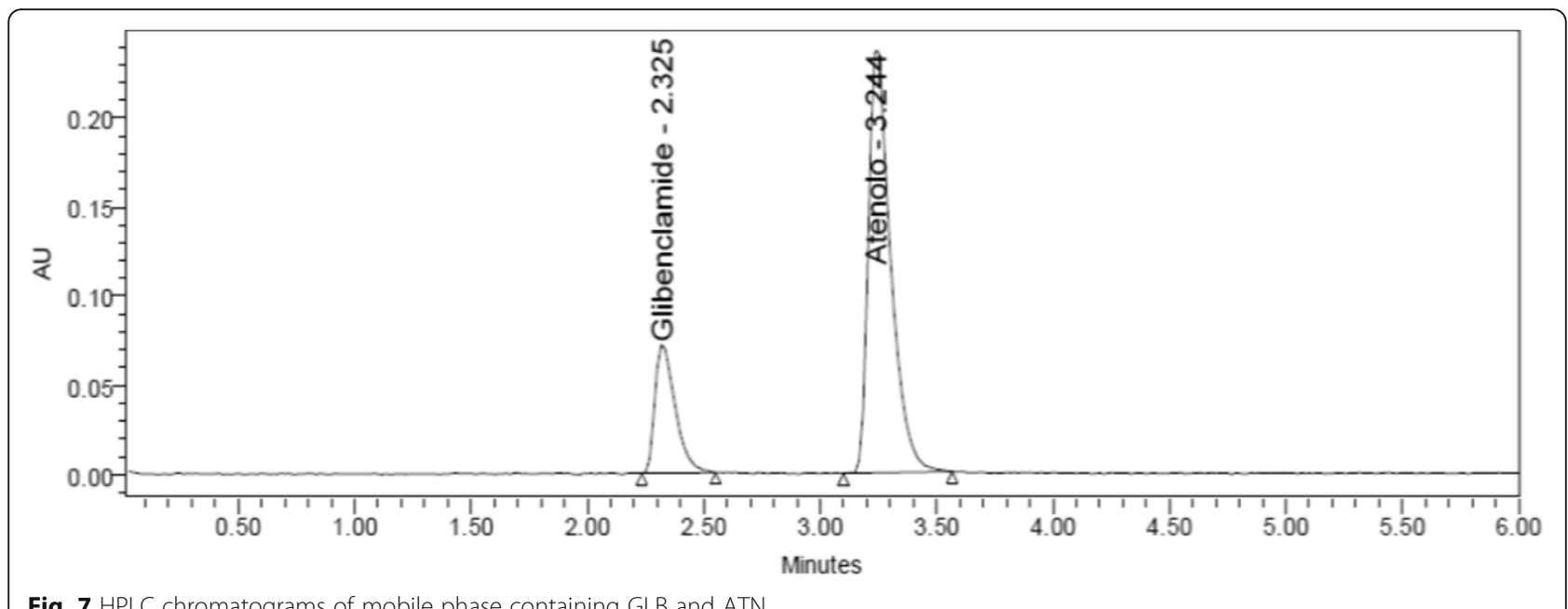

Fig. $7 \mathrm{HPLC}$ chromatograms of mobile phase containing GLB and ATN

low boiling point. The higher enhancement of limonene may also be attributed to its low boiling point. The low boiling points of terpenes indicate the weak cohesiveness or self-association of the molecules and therefore they may more easily associate or interact with lipid components of stratum corneum and alter the barrier property. Furthermore, invasomes with D-limonene showed further penetration due to their higher lipophilic and lower boiling point, which is also reported in earlier work [47]. The permeation into the skin is increased to 3.87 -fold when it contains $1 \%$ terpenes which are reported in previous work $[48,49]$.

\section{Response 4 (Y4): effect of independent variables on flux of ATN}

Transdermal flux of ATN increased on increasing the phospholipid content in the formulation. The 3Dresponse graph (Fig. 2d) showed that on increasing the phospholipid content in formulations, higher transdermal flux of ATN was observed [50]. Moreover, the transdermal flux is also increased on increasing ethanol content. Terpene also plays a substantial role in the permeation enhancement of hydrophilic as well as lipophilic drug. In our study, terpene such as D-limonene showed a positive relationship with ATN and GLB flux. The most optimum concentration of the selected variables was determined using the "point optimization" feature.

Table 6 Ex vivo permeation data of OCNIG

\begin{tabular}{llll}
\hline S. & $\begin{array}{l}\text { Ex vivo } \\
\text { No. }\end{array}$ & permeation & Flux $\left(\boldsymbol{\mu g} / \mathbf{c m}^{2} / \mathbf{h}\right)$ \\
\cline { 3 - 4 } & Rabbit Skin (OCNIG) & $240.43 \pm 1.76$ & ATN \\
\hline 1 & Control (Patches) & $175.34 \pm 1.23$ & $355.76 \pm 1.54$ \\
2 & &
\end{tabular}

Experimental values of these independent variables yielded by the ONIG were found to be in agreement with the predicted values, which imply that the optimized formulation was rational and reliable.

\section{NI characterization}

The prepared NI gel was considered acceptable with no skin irritation and having a less vesicle size which facilitates their permeation. The NI gels which are formulated were light in color with uniform appearance and texture with absence of lumps. A gel with good spreadability takes less time to spread [21]. The developed gel of OCNIG presented 90\% spreadability with excellent extrudability. Viscosity is a significant factor for describing the gels as it affects the extrudability and release of drugs. Ethanol interpenetrates into the hydrocarbon chains and alters the net charge of the vesicles and decreases its mean vesicle size. Furthermore, ethanol-based nanovesicles have been reported more stable under storage condition possibly due to generation of negative surface charge and electrostatic repulsion which restrict vesicle aggregation. The image of TEM showed well-identified spherical nano vesicular and homogenous with sharp boundaries.

\section{Evaluation of stability of OCNIG}

The results revealed a no considerable change between the newly prepared and the stored formulation. It was concluded that the prepared OCNIG has good stability under storage conditions [51-53].

\section{HPLC determination of GLB and ATN}

The analytical method for simultaneous estimation of GLB and ATN was validated. Validated analytical method was found acceptable and proved to be adequate for the determination of GLB and ATN in plasma [26]. 

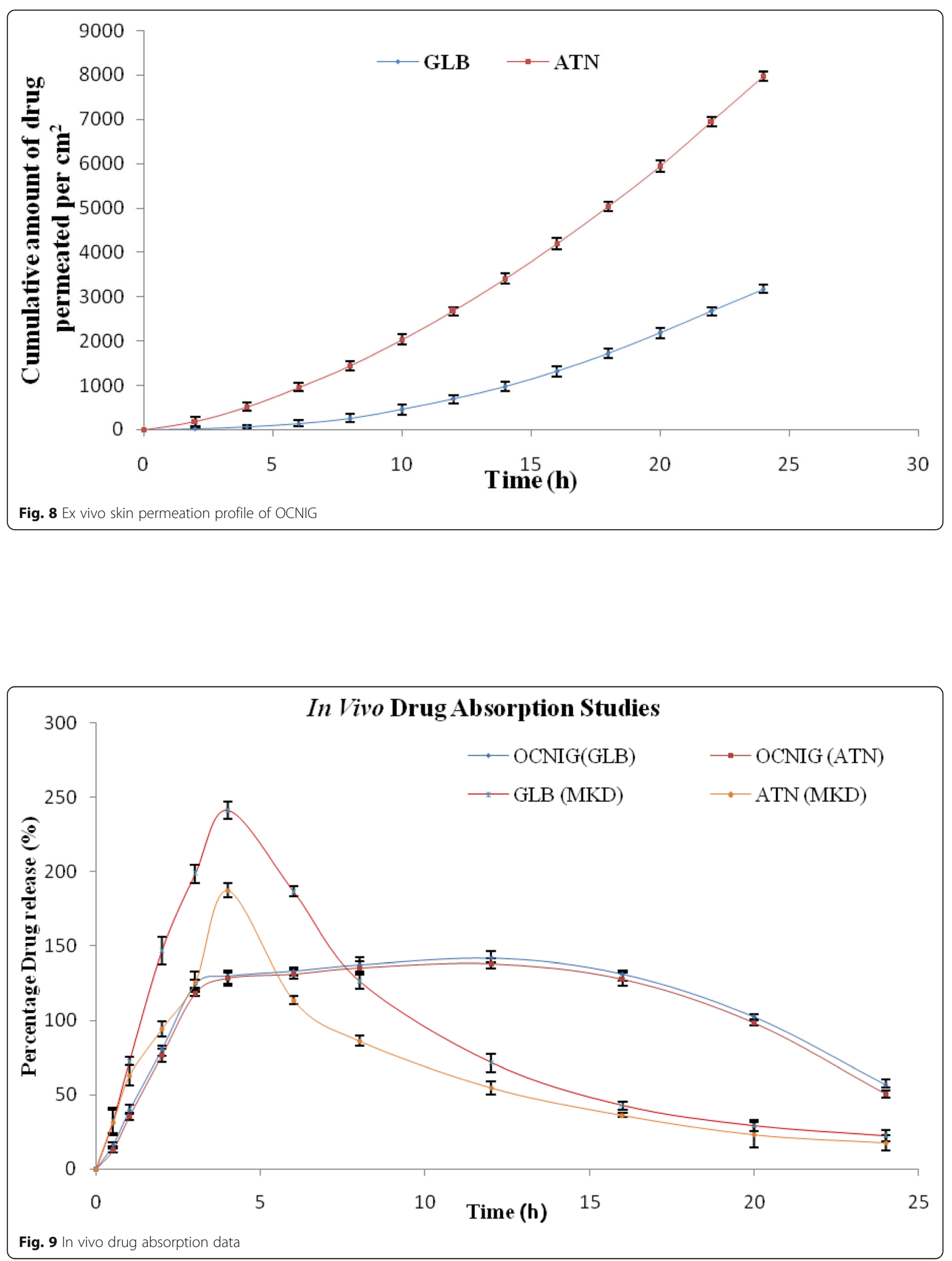
Table 7 Pharmacokinetic parameters of ATN and GLB in rabbits

\begin{tabular}{|c|c|c|c|c|c|}
\hline \multirow{2}{*}{$\begin{array}{l}\text { S. } \\
\text { No }\end{array}$} & \multirow{2}{*}{$\begin{array}{l}\text { Pharmaco- } \\
\text { kinetic } \\
\text { parameters }\end{array}$} & \multicolumn{2}{|c|}{ Marketed formulation } & \multicolumn{2}{|c|}{ OCPG formulation } \\
\hline & & $\overline{\text { GLB }}$ & ATN & $\overline{\mathrm{GLB}}$ & ATN \\
\hline 1 & $T_{\max }(\mathrm{h})$ & $4 \pm 0.53$ & $4 \pm 0.08$ & $13.00 \pm 0.24$ & $13.00 \pm 0.05$ \\
\hline 2 & $C_{\max }(\mathrm{ng} / \mathrm{ml})$ & $251.58 \pm 10.52$ & $177.62 \pm 10.14$ & $151.76 \pm 12.15$ & $127.64 \pm 10.06$ \\
\hline 3 & $A \cup C_{0-t}(\mathrm{ng} \mathrm{h} / \mathrm{ml})$ & $2226.88 \pm 2.31$ & $1422.6 \pm 2.58$ & $2930.21 \pm 3.15$ & $2838.94 \pm 1.91$ \\
\hline 4 & $A \cup C_{0-\infty}(\mathrm{ng} \mathrm{h} / \mathrm{ml})$ & $2357.93 \pm 1.24$ & $1576.48 \pm 4.24$ & $3362.37 \pm 2.22$ & $3122.55 \pm 1.35$ \\
\hline 5 & $t_{1 / 2}$ & $9.54 \pm 0.07$ & $8.45 \pm 0.04$ & $16.945 \pm 1.24$ & $14.786 \pm 1.23$ \\
\hline 6 & MRT & 12.543 & 11.759 & 17.087 & 15.432 \\
\hline 7 & $\mathrm{~F} \%$ & - & - & 134.30 & 180.32 \\
\hline
\end{tabular}

\section{In vitro drug release and release kinetics}

The coefficient of determination obtained after fitting the in vitro permeation data to the respective model equation indicate that the best fit model was the Higuchi's model for nano-invasomes gel. Higuchi describes drug release as a diffusion process based on the Fick's law, square root time dependent. This relation can be used to describe the drug dissolution from several types of modified release pharmaceutical dosage forms, as in the case of some transdermal systems which was reported by previous researchers [54].

\section{Ex vivo skin permeation study}

The percentage of drug diffused through the rabbit skin was assessed. The Box-Behnken design relationship has been established between independent and dependent variables. This helped to understand the exact factors affecting the response of the prepared NI. More drug permeation was observed from the OCNIG when compared to transdermal patches [55].

\section{In vivo pharmacokinetic study}

The plasma concentration-time profiles of GLB and ATN of marketed suspension and OCNIG are shown in Fig. 9. The pharmacokinetic parameters were given in Table 6. The values showed that $C_{\text {max }}$ of the OCNIG was significantly ( $p$ $<0.001$ ) lower than the oral marketed suspension. Higher AUC values which are preferable to the upkeep of the concentration of the drug within the pharmacological effective range for a longer period of time, which is similar to findings of previous researchers [56, 57]. Increased bioavailability of the drugs can be identified due to significant $(p<0.002)$ high $\mathrm{AUC}_{0-24}$ values. The increased $t_{1 / 2}$ GLB and ATN in plasma was noticed after the application of OCNIG which is

Table $\mathbf{8}$ Draize score for all groups of rabbits

\begin{tabular}{|c|c|c|c|c|c|c|}
\hline \multirow{2}{*}{$\begin{array}{l}\text { S. } \\
\text { No. }\end{array}$} & \multicolumn{2}{|l|}{ Control } & \multicolumn{2}{|l|}{ Blank } & \multicolumn{2}{|c|}{ Test (OCNIG) } \\
\hline & Erythema & Edema & Erythema & Edema & Erythema & Edema \\
\hline Score & 0 & 0 & 0 & 0 & 0 & 0 \\
\hline
\end{tabular}

confirmed by previous findings $[16,58]$. The $\% \mathrm{~F}$ was found to be $135 \%$ for GLB and $180 \%$ for ATN [59] when compared with oral preparations.

\section{Skin irritation studies}

Based on the findings, the skin irritation study showed that the developed OCNIG applied was not irritable. It was considered safe for transdermal operation [60].

\section{Pharmacodynamic study}

In the present study, GLB NI gel and OCNIG produced significant hypoglycemic effects in STZ-induced diabetic rats. Due to the induction of diabetes by STZ, there is a significant increase in fasting blood glucose levels in diabetic rats [61]. Formulation OCNIG was successful in reducing the blood glucose levels to normal values, whereas the oral marketed GLB unsuccessful in blood glucose level reduction [62, 63]. Results of in vivo antihypertensive activity clearly indicate that the OCNIG released the drug gradually over a period of time, which resulted in prolonged control of hypertension up to 24 h. Formulation OCNIG was successful in reverting the rat BP to normal values, whereas orally failed to reduce the BP maximum period [64]. The result indicated that the transdermal administration of ONIG was capable of producing prolonged release of ATN, similar to the effect of ATN-loaded NIG formulation. The above results suggest that the developed OCNIG holds promise for the management of diabetes and hypertension that must be validated by clinical trials.

\section{Conclusion}

The administration of therapeutants via the skin has many advantages over other methods of administration. Within this framework, we optimized and evaluated the transdermal administration of a combined nanoinvasomal gel that contains active molecules to treat concurrent diseases, including diabetes with hypertension. It plays an important role in the administration of medications with increased skin penetration and drug absorption. Here, widely used antidiabetic and antihypertensive since adherence with these medicines is quite short, and the use of this combination is to 


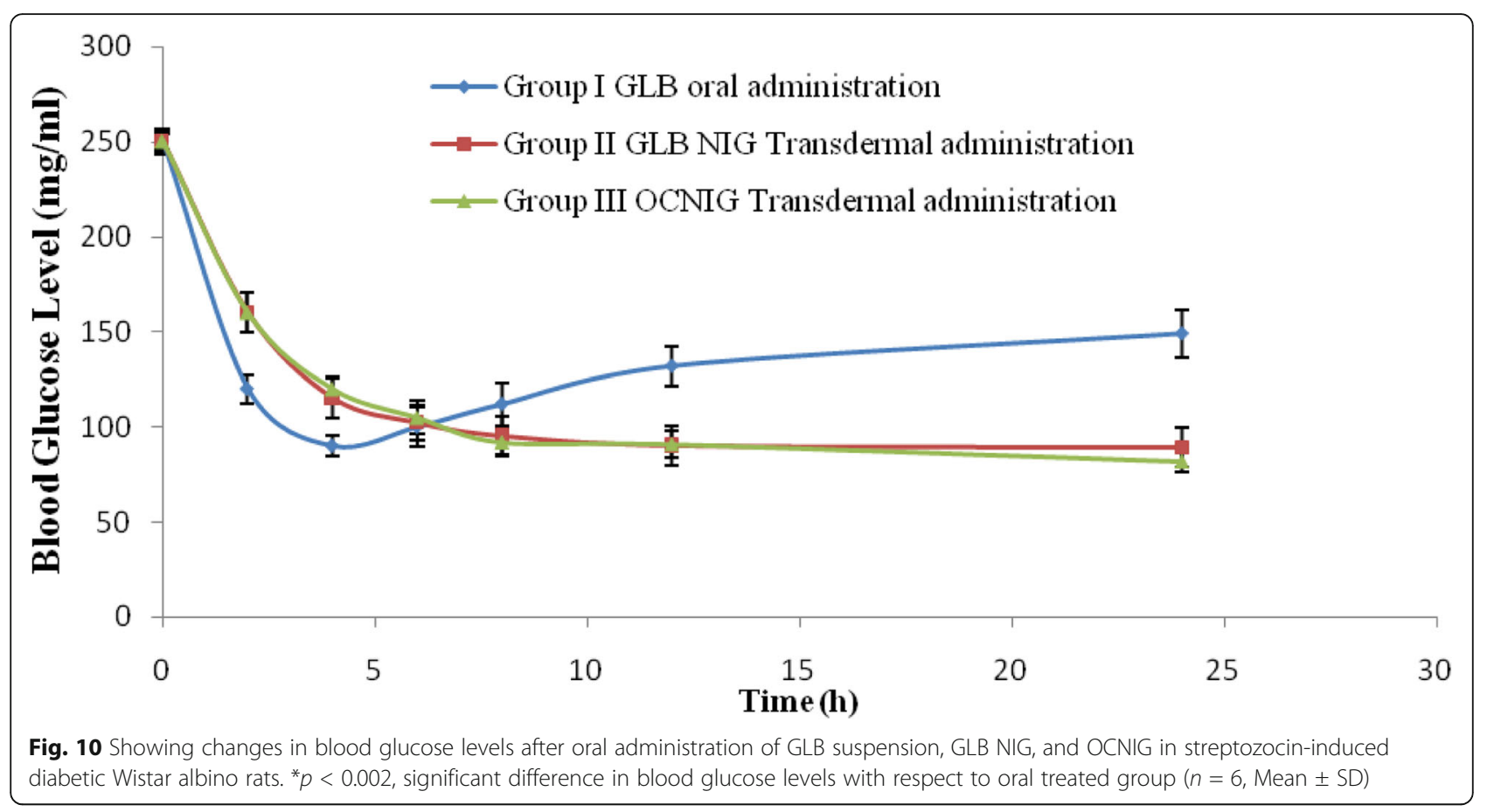

manage long-acting medication, which releases drugs at the same time, simplifies complex therapeutic regimen, and to better acceptability and adherence. In pharmacodynamic and in vivo assays, therapeutic doses of drugs were given to rats in a sustained manner, which demonstrated the potential of this combined route of administration. Perhaps the increased use of fixed-dose combination therapy may make it easier for our patients to remember to take their medications especially in comorbid conditions and get them to goal quicker and with less trouble. This should improve the rates of blood pressure control and ultimately accelerate the reduction in cardiovascular disease events attributable to hypertension in diabetic patient. Hence, they can open up new challenges and opportunities for the development of novel improved therapies.

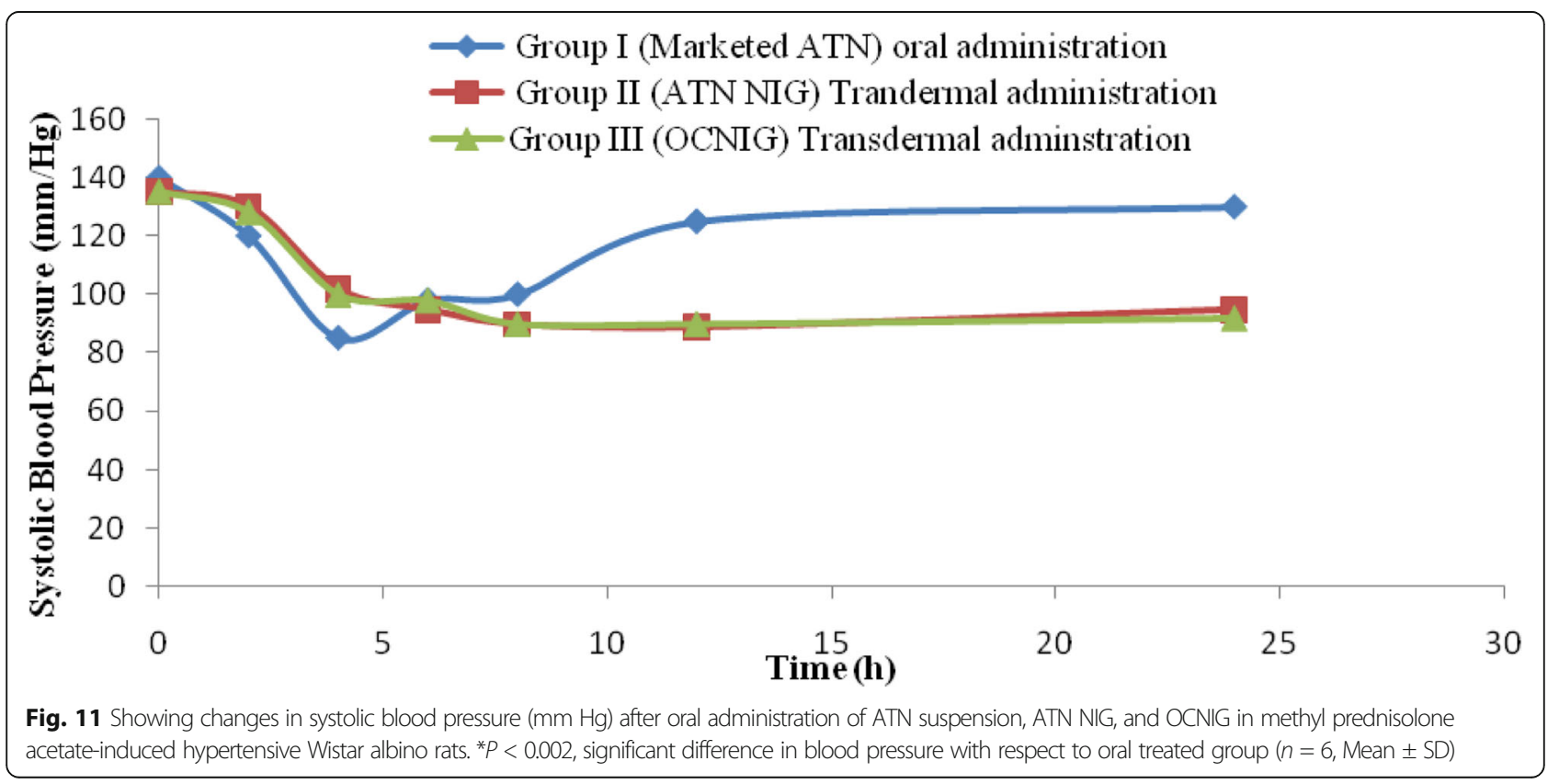


Combinational nano invasomal gel represents a promising technology that could be used for transdermal delivery of many other established drugs which are used for treating these types of concurrent diseases.

\author{
Abbreviations \\ NI: Nano invasomes; PDI: Polydispersity index; BCS: Biopharmaceutics \\ Classification System; GLB: Gliblenclamide; ATN: Atenolol; EE: Entrapment \\ efficiency; TEM: Transmission electron microscopy; OCNIG: Optimized \\ combinational nano invasomal gel; ICH: The International Council for \\ Harmonization; HPLC: High-performance liquid chromatography; \\ PBS: Phosphate buffer saline; $C_{\text {max }}$ : Maximum plasma drug concentration; \\ AUC: Area under the curve; $T_{\text {max }}$ : Peak plasma drug concentration; \\ SBP: Systolic blood pressure
}

\section{Acknowledgements}

The authors are thankful to Dr. S Ramkanth, Karpagam College of Pharmacy, Coimbatore, Dr. D. Swarnalatha, Principal, Annamacharya College of Pharmacy, Rajampeta and Dr. J Jaslin Edward, Cape Biolab \& Research Centre, Marthandam for providing all facilities and their immense support for our work.

\section{Authors' contributions}

PA and SVSN designed all the experiments. PA performed the experiment, analyzed the data, and wrote the manuscript. SVSN provided all the needed information. The authors read and approved the final manuscript.

\section{Funding}

No funding

\section{Availability of data and materials}

All the data and materials are available upon request.

\section{Declarations}

\section{Ethics approval and consent to participate}

In this study, all the procedures using Male New Zealand rabbits, weighed $2.5-3.0 \mathrm{~kg}$, were provided by the Institutional Animal Ethical Committee of Annamacharya college of Pharmacy, Rajampet, India and approved certificates of conformity: 1220/PO/Re/S/08/CPCSEA. All the procedures using Male Wistar albino rats, weighed 150-180 g, were provided by the Institutional Animal Ethical Committee of CAPE Biolab and Research center, Marthandam, Tamilnadu, India and approved certificates of conformity: IAEC No. CBLRC/ IAEC/ 13/ 01-2019.

\section{Consent for publication}

Not applicable.

\section{Competing interests}

The authors declare no conflicts of interest.

\section{Author details}

'Department of Pharmaceutics, Research Scholar, JNTUA, Anantapuramu, AP, India. ${ }^{2}$ Department of Chemical Engineering, JNTUA, Anantapuramu, AP, India.

Received: 15 January 2021 Accepted: 3 April 2021

Published online: 26 April 2021

\section{References}

1. Li J, Wang S, Zhang G, Zhang G, Zhao M, Ma L (2020) Spatiotemporal trends and influence factors of global diabetes prevalence in recent years. Soc Sci Med 256:113062. https://doi.org/10.1016/j.socscimed.2020.113062

2. Hypertension in Diabetes Study (HDS) (1993) Prevalence of hypertension in newly presenting type 2 diabetic patients and the association of risk factors for cardiovascular and diabetic complicatins. J Hypertns 11(3):309-317. https://doi.org/10.1097/00004872-199303000-00012

3. Hubbard RE, O'Mahony MS, Woodhouse KW (2013) Medication prescribing in frail older people. Eur J Clin Pharmacol 69(3):319-326. https://doi.org/10.1 007/s00228-012-1387-2
4. Benjamin RM (2012) Medication adherence: helping patients take their medicines as directed. Public Health Rep 127(1):2-3. https://doi.org/10.1177/ 003335491212700102

5. Gourgari E, Wilhelm EE, Hassanzadeh H, Aroda VR, Shoulson I (2017) A comprehensive review of the FDA-approved labels of diabetes drugs: indications, safety, and emerging cardiovascular safety data. J Diabetes Complicat 31(12):1719-1727. https://doi.org/10.1016/j.jdiacomp.2017.08.005

6. Hao Y, Li W, Zhou X, Yang F, Qian Z (2017) Microneedles-based transdermal drug delivery systems: a review. J Biomed Nanotechnol 13(12):1581-1597. https://doi.org/10.1166/jbn.2017.2474

7. Zhou X, Hao Y, Yuan L, Pradhan S, Shrestha K, Pradhan O, Liu H, Li W (2018) Nanoformulations for transdermal drug delivery: a review. Chin Chem Lett 29(12):17131724 http.//unw.chinchemlett.com.cn/EN/10.1016/.cclet.2018.10.037

8. Dwivedi M, Sharma V, Pathak K (2017) Pilosebaceous targeting by isotretenoin-loaded invasomal gel for the treatment of eosinophilic pustular folliculitis: optimization, efficacy and cellular analysis. Drug Dev Ind Pharm 43(2):293-304. https://doi.org/10.1080/03639045.2016.1239628

9. Dragicevic-Curic N, Scheglmann D, Albrecht V, Fahr A (2008) Temoporfinloaded invasomes: development, characterization and in vitro skin penetration studies. J Control Release 127(1):59-69. https:/doi.org/10.1016/j.jconrel.2007.12.013

10. Essa EA, Elkot FE, Zin Eldin EE, El Maghraby GM (2015) Development and evaluation of glibenclamide floating tablet with optimum release. J Drug Deliv Sci Technol 27:28-36. https://doi.org/10.1016/j.jddst.2015.04.002

11. Liu H, Shang K, Liu W, Leng D, Li R, Kong Y, Zhang T (2014) Improved oral bioavailability of glyburide by a self-nanoemulsifying drug delivery system. J Microencapsul 31(3):277-283. https://doi.org/10.3109/02652048.2013.843598

12. Shrivastava AK, Wadhwa S, Poonam D, Ridhuekar MB (2005) Oral sustained delivery of atenolol from floating matrix tablets - formulation and in vitro evaluation. Drug Dev Ind Pharm 31(4-5):367-371. https://doi.org/10.1081/ DDC-54313

13. Thyagarajan A, Sam Johnson Udaya Chander J, Senthil Kumar C, Sreenivasan $V$, Venkata Narayanan R (2015) Preparation, in vitro characterization of transdermal patch containing atenolol and hydrochlorothiazide: a combinational approach. J Appl Pharm Sci 5(3):033-039. https://doi.org/10. 7324/JAPS.2015.510.56

14. Mokale VJ, Patil HI, Patil AP, Shirude PR, Naik JB (2016) Formulation and optimisation of famotidine proniosomes: an in vitro and ex vivo study. J Exp Nanosci 11(2):s97-s110. https://doi.org/10.1080/17458080.2015.1030711

15. Shah SM, Ashtikar M, Jain AS, Makhija DT, Nikam Y, Gude RP, Steiniger F, Jagta AA, Nagarsenker MS, Fahr A (2015) LeciPlex, invasomes, and liposomes: a skin penetration study. Int J Pharm 490(1-2):391-403. https:// doi.org/10.1016/j.jpharm.2015.05.042

16. Kamran M, Ahad A, Aqil M, Imamc SS, Sultana Y, Ali A (2016) Design, formulation and optimization of novel soft nano-carriers for transdermal olmesartan medoxomil delivery: In vitro characterization and in vivo pharmacokinetic assessment. Int J Pharm 505(1-2):147-158. https://doi.org/1 0.1016/j.jpharm.2016.03.030

17. Sampathi S, Mankala SK, Wankar J, Dodoala (2015) Nanoemulsion based hydrogels of itraconazole for transdermal drug delivery. J Sci Ind Res 74:88$92 \mathrm{http} / / /$ hdl.handle.net/123456789/30449

18. Moghddam SMM, Ahad A, Aqil M, Imam SS, Sultana Y (2017) Optimization of nanostructured lipid carriers for topical delivery of nimesulide using boxBehnken design approach. Artif Cells Nanomed Biotechnol 45(3):617-624. https://doi.org/10.3109/21691401.2016.1167699

19. Ahad A, Raish M, Al-Mohizea AM, Al-Jenoob Fl, Alam MA (2014) Enhanced anti-inflammatory activity of carbopol loaded meloxicam nanoethosomes gel. Int J Biol Macromol 67:99-104. https://doi.org/10.1016/j.jibiomac.2014. 03.011

20. Qumbara M, Ameeduzzafarb SSI, Alia J, Ahmadd J, Ali A (2017) Formulation and optimization of lacidipine loaded niosomal gel for transdermal delivery: in-vitro characterization and in-vivo activity. Biomed Pharmacother 93:255266. https://doi.org/10.1016/j.biopha.2017.06.043

21. Bachha YG, Patravale VB (2009) Microemulsion based vaginal gel of fluconazole: formulation, in vitro and in vivo evaluation. Int J Pharm 365(12):175-179. https://doi.org/10.1016/j.jpharm.2008.08.021

22. Chaudhary H, Kohli K, Amin S, Rathee P, Kumar V (2011) Optimization and formulation design of gels of diclofenac and curcumin for transdermal drug delivery by box-Behnken statistical design. J Pharm Sci 100(2):580-593. https://doi.org/10.1002/jps.22292

23. Khatoon M, Sohail MF, Shahnaz G, Rehman FU, Fakhar-Ud-Din AUR, Ullah N, Amin U, Khan GM, Shah KU (2019) Development and evaluation of 
optimized thiolated chitosan proniosomal gel containing duloxetine for intranasal delivery. AAPS PharmSciTech 20(7):288. https://doi.org/10.1208/ s12249-019-1484-y

24. Alam S, Aslam M, Khan A, Imam SS, Aqil M, Sultana Y, Ali A (2014) Nanostructured lipid carriers of pioglitazone for transdermal application: from experimental design to bioactivity detail. Drug Deliv, Early Online:1-9. https://doi.org/10.3109/10717544.2014.923958

25. Song S, Tian B, Chen F, Zhang W, Pan Y, Zhang Q, Yang X, Pan W (2015) Potentials of proniosomes for improving the oral bioavailability of poorly water-soluble drugs. Drug Dev Ind Pharm Early Online 41(1):1-12. https:// doi.org/10.3109/03639045.2013.845841

26. Anitha P, Ramkanth S, Satyanarayana SV (2019) Development and validation of a new analytical RP-HPLC method for simultaneous determination of Glibenclamide and atenolol in bulk. Int J Res Pharm Sci 10(3):2433-2445. https://doi.org/10.26452/ijrps.v10i3.1491

27. El-Maghraby GM, Ahmed AA, Osman MA (2015) Penetration enhancers in proniosomes as a new strategy for enhanced transdermal drug delivery. Saudi Pharm J 23(1):67-74. https://doi.org/10.1016/j.jsps.2014.05.001

28. Higuchi T (1963) Mechanism of sustained- action medication. Theoretical analysis of rate of release of solid drugs dispersed in solid matrices. J Pharm Sci 52(12):1145-1149. https://doi.org/10.1002/jps.2600521210

29. Korsmeyer RW, Gurny R, Doelker E, Buri P, Peppas NA (1983) Mechanisms of solute release from porous hydrophilic polymers. Int J Pharm 15(1):25-35. https://doi.org/10.1016/0378-5173(83)90064-9

30. Anitha P, Ramkanth S, Saleem MTS, Umasankari K, Reddy BP, Chetty M (2011) Preparation, in-vitro and in-vivo characterization of transdermal patch containing Glibenclamide and atenolol: a combinational approach. Pak J Pharm Sci 24(2):155-163

31. Ahad A, Aqil M, Kohli K, Sultana Y, Mujeeb M (2011) Interactions between novel terpenes and main components of rat and human skin: mechanistic view for transdermal delivery of propranolol hydrochloride. Curr Drug Deliv 8(2):213-224. https://doi.org/10.2174/156720111794479907

32. de Almeida Borges VR, Simon A, Sena ARC, Cabral LM (2013) Nanoemulsion containing dapsone for topical administration: a study of in vitro release and epidermal permeation. Int J Nanomedicine 8:535-544. https://doi.org/1 $0.2147 /$ IJN.S39383

33. de Sousa VP (2014) Preparation, characterization and stability study of dutasteride loaded nanoemulsion for treatment of benign prostatic hypertrophy. Iran J Pharm Res 13(4):1125-1140

34. Trauer S, Richter $H$, Kuntsche J, Buttemeyer R, Liebsch M, Linscheid M, Fahr A, Schafer-Korting M, Lademann J, Patzelt A (2014) Influence of massage and occlusion on the ex vivo skin penetration of rigid liposomes and invasomes. Eur J Pharm Biopharm 86(2):301-306. https://doi.org/10.1016/j. ejpb.2013.11.004

35. Shah S, Asnani A, Kawade D, Dangre S, Arora S, Yende S (2012) Simultaneous quantitative analysis of olmesartan medoxomil and amlodipine besylate in plasma by high-performance liquid chromatography technique. J Young Pharm 4(2):88-94. https://doi.org/10.4103/0975-1483. 96622

36. Draize $\mathrm{JH}$, Woodard $\mathrm{CHO}$ (1944) Methods for the study of irritation and toxicity of substances applied topically to the skin and mucous membranes. J Pharmacol Exp Ther 82:377-390

37. Xu L, Pan J, Chen Q, Yu Q, Chen H, Xu H, Qiu Y, Yang X (2008) In vivo evaluation of the safety of triptolide-loaded hydrogel-thickened microemulsion. Food Chem Toxicol 46(12):3792-3799. https://doi.org/10.1016/j.fct.2008.09.065

38. Aqil M, Sultana Y, Ali A, Dubey K, Najmi AK, Pillai KK (2004) Transdermal drug delivery systems of a beta blocker: design, in vitro, and in vivo characterization. Drug Deliv 11(1):27-31. https://doi.org/10.1080/10717540490265225

39. Sridevi S, Chary MG, Krishna DR, Prakash Diwan V (2000) Pharmacodynamic evaluation of transdermal drug delivery system of glibenclamide in rats. Indian J Pharm 32:309-312

40. Kubota Y, Umegaki K, Kagota S, Tanaka N, Nakamura K, Kunitomo M Shinozuka K (2006) Evaluation of blood pressure measured by tail-cuff methods (without heating) in spontaneously hypertensive rats. Biol Pharm Bull 29(8):1756-1758. https://doi.org/10.1248/bpb.29.1756

41. Ahad A, Aqil M, Ali A (2014) Investigation of antihypertensive activity of Carbopol valsartan transdermal gel containing 1,8-cineole. Int J Biol Macromol 64:144-149. https://doi.org/10.1016/j.ijbiomac.2013.11.018

42. Gajra B, Dalwadi C, Patel (2015) Formulation and optimization of itraconazole polymeric lipid hybrid nanoparticles (Lipomer) using box behnken design. Daru 23(1):3. https://doi.org/10.1186/s40199-014-0087-0
43. Mukherjee B, Patra B, Layek B, Mukherjee A (2007) Sustained release of acyclovir from nano-liposomes and nano-niosomes: an in vitro study. Int J Nanomedicine 2:213-225

44. Khatoon M, Sohail MF, Shahnaz G, Rehman F u, Asim ur Rehman F-u-D, Ullah N, Amin U, Khan GM, Shah KU (2019) Development and evaluation of optimized thiolated chitosan proniosomal gel containing duloxetine for intranasal delivery. AAPS PharmSciTech 20(7):288. https://doi.org/10.1208/ s12249-019-1484-y

45. Badran MM, Kuntsche J, Fahr A (2009) Skin penetration enhancement by a microneedle device (Dermaroller ${ }^{\circledR}$ ) in vitro: dependency on needle size andapplied formulation. Eur J Pharm Sci 36(4-5):511-523. https://doi.org/1 0.1016/j.ejps.2008.12.008

46. Hoflan HE, van der Geest R, Bodde H, Junginger HE, Bouwstra JA (1994) Estradiol permeation from nonionic surfactant vesicles through human stratum corneum in vitro. Pharm Res 11(5):659-664. https://doi.org/10.1 023/A:1018963910260

47. Bilek H, Wonglertnirant N, Ngawhirunpat T, Opanasopita P, Vollrath MK (2009) Effect of terpenes on the skin permeation of Ketoprofe through shed snake skin. Silpakorn U Sci Tech J 3:33-41

48. Kalpana B, Lakshmi PK (2013) Transdermal permeation enhancement of Tolterodine tartrate through invasomes and iontophoresis. Pharm Lett 5: 119-126

49. Curic ND, Scheglmann D, Albrecht V, Fahr A (2009) Development of different temoporfin-loaded invasomes-novel nanocarriers of temoporfin: characterization, stability and in vitro skin penetration studies. Colloids Surf A Physicochem Eng Asp B70:198-206. https://doi.org/10.1016/j.colsurfb.2008.12.030

50. Verma DD, Fahr A (2004) Synergistic penetration enhancement effect of ethanol and phospholipids on the topical delivery of cyclosporine. J Control Release 97(1):55-66. https://doi.org/10.1016/j.jconrel.2004.02.028

51. Qadri GR, Ahad A, Aqil M, Imam SS, Ali A (2017) Invasomes of isradipine for enhanced transdermal delivery against hypertension: formulation, characterization, and in vivo pharmacodynamic study. Artif Cell Nanomed B 45(1):139-145. https://doi.org/10.3109/21691401.2016.1138486

52. Demiana Nesseem I, Eid SF, El-Houseny SS (2011) Development of nove transdermal self-adhesive films for tenoxicam, an anti-inflammatory drug. Life Sci 89(13-14):430-438. https://doi.org/10.1016/j.lfs.2011.06.026

53. Balakrishnan P, Shanmugam S, Lee WS, Lee WM, Kim JO, Dong Hoon O, Kim D-D, Kim JS, Yoo BK, Choi H-G, SooWoo J, Yong CS (2009) Formulation and in vitro assessment of minoxidil niosomes for enhanced skin delivery. Int J Pharm 377(1-2):1-8. https://doi.org/10.1016/j.ijpharm.2009.04.020

54. Pathana IB, Jawarea BP, Shelkeb S, Ambekar W (2018) Curcumin loaded ethosomes for transdermal application: formulation, optimization, in-vitro and in-vivo study. J Drug Deli Sci Tech 44:49-57. https://doi.org/10.1016/j. jddst.2017.11.005

55. Bisht D, Verma D, Mirza M, Anwer MK, lqbal Z (2017) Development of ethosomal gel of ranolazine for improved topical delivery: in vitro and ex vivo evaluation. J Mol Liq 225:475-481. https://doi.org/10.1016/j.molliq.2 016.11 .114

56. Monica G, Jovita K, Sanjay T, Shubhini SA (2014) Development of piroxicam loaded nanostructured lipid carriers for spondylitis treatment. Adv Sci Lett 20(5):1066-1071. https://doi.org/10.1166/asl.2014.5487

57. Aqil M, Kamran M, Ahad A, Ima SS (2016) Development of clove oil based nanoemulsion of olmesartan for transdermal delivery: box-Behnken design optimization and pharmacokinetic evaluation. J Mol Liq 214:238-248. https://doi.org/10.1016/j.molliq.2015.12.077

58. Ismail S, Khatta A (2018) Optimization of proniosomal itraconazole formulation using box Behken design to enhance oral bioavailability. J Drug Del Sci Tech 45:142-150. https://doi.org/10.1016/j.jddst.2018.03.013

59. Moolakkadath T, Aqil M, Ahad A, Imam SS, Iqbal B, Sultana Y, Mujeeb M, labal Z (2018) Development of transethosomes formulation for dermal fisetin delivery: box-Behnken design, optimization, in vitro skin penetration, vesicles-skin interaction and dermatokinetic studies. Artif Cells Nanomed Biotechnol 46(2):S755-S765. https://doi.org/10.1080/21691401.2018.1469025

60. Imam SS, Aquil M, Akhtar M et al (2015) Formulation by design-based proniosomes for accentuated transdermal delivery of Risperidone: in vitro characterization and in-vivo pharmacokinetic study. Drug Deliv 22(8):10591070. https://doi.org/10.3109/10717544.2013.870260

61. Khan MA, Pandit J, Sultana Y, Sultana S, Ali A, Aqil M, Chauhan M (2014) Novel carbopol-based transfersomal gel of 5-fluorouracil for skin cancer treatment: in vitro characterization and in vivo study. Drug Del:1-8. https:// doi.org/10.3109/10717544.2014.902146 
62. Alam MS, Ahad A, Abidin L, Aqil M, Mir SR, Mujeeb M (2018) Embelinloaded oral niosomes ameliorate streptozotocin-induced diabetes in Wistar rats. Biomed Pharmacother 97:1514-1520. https://doi.org/10.1016/j.biopha.2 017.11 .073

63. Vijayan V, Ravindra Reddy K, Sakthivel S, Swetha C (2013) Optimization and charaterization of repaglinide biodegradable polymeric nanoparticle loaded transdermal patchs: In vitro and in vivo studies. Colloids Surf B 111:150-155. https://doi.org/10.1016/j.colsurfb.2013.05.020

64. Ahad A, Al-Saleh AA, Al-Mohizea AM, Al-Jenoobi Fl, Raish M, Yassin AEB, Alam MA (2017) Pharmacodynamic study of eprosartan mesylate load transfersomes Carbopol1 gel under Dermaroller1 on rats with methyl prednisolone acetate-induced hypertension. Biomed Pharmacother 89:177184. https://doi.org/10.1016/j.biopha.2017.01.164

\section{Publisher's Note}

Springer Nature remains neutral with regard to jurisdictional claims in published maps and institutional affiliations.

\section{Submit your manuscript to a SpringerOpen ${ }^{\circ}$ journal and benefit from:}

- Convenient online submission

- Rigorous peer review

- Open access: articles freely available online

- High visibility within the field

- Retaining the copyright to your article

Submit your next manuscript at $\boldsymbol{\nabla}$ springeropen.com 